\title{
KONTESTASI LOYALIS, KRITIKUS DAN ORIENTALIS TENTANG WAHHABISME
}

\author{
Badrus Samsul Fata \\ Pascasarjana Universitas Islam Negeri Syarif Hidayatullah Jakarta \\ badrusfata@gmail.com
}

\begin{abstract}
Abstrak
Sejak kemunculannya, Wahhabisme telah menjadi sasaran kontestasi antara loyalis dan kritikus. Para loyalis telah menggambarkan Wahhabisme sebagai gerakan puritan, revivalis, modern dan bahkan gerakan reformasi teologis Islam. Di sisi lain, para kritikus telah memposisikan Wahhabisme sebagai teologi sesat (bid'ah), ideologi dan gerakan subversif dan menyesatkan, menyimpang dari jalan salaf al-sălih. Apa yang masih hilang dalam potret ini adalah wacana orientalis tentang Wahhabisme. Dengan menggunakan teori postkolonial yang tersedia saat ini, makalah ini membahas wacana orientalis tentang Wahhabisme dan mengkaji bagaimana mereka telah membentuk studi Islam dalam lingkungan akademik kontemporer.
\end{abstract}

Kata Kunci: Orientalisme, Wahhabisme, Poskolonialisme

\section{Abstract}

Since its emergence, Wahhabism has been subject to contestation between loyalists and critics. The loyalists have been portraying Wahhabism as a puritan, revivalist, modern and even an Islamic theological reform movement. On the other hand, the critics have been positioning Wahhabism as a heretical theology (bid'ah), a subversive and misleading ideology and movement, deviating from the pious paths of most forefathers (salaf al-sālih). What is still missing in the picture is the orientalist discourses on Wahhabism. Using the currently available postcolonial theories, this paper will discuss the orientalist discourses on Wahhabism and examine how they has been shaped Islamic studies in the contemporary academic milieu.

Keywords: Orientalism, Wahhabism, Postcolonialism 


\section{Pendahuluan}

Salah satu pioneer pendekatan kritis dalam studi orientalis adalah Edward W. Said melalui karya masterpiece-nya, Orientalism. ${ }^{1}$ Dalam perkembangannya, orientalisme menuai kritik, namun juga menginspirasi munculnya varian baru, yakni teori diskursus kolonial dan makin diperuncing dengan munculnya teori poskolonialisme. Menurut Said dan para koleganya, teori ini adalah kritik sekaligus evaluasi atas berbagai ketidakakuratan asumsi-asumsi diskursif dan paradigma pemikiran barat yang selama ini diterima secara taken for granted, baik pada level individu, akademisi maupun stakeholder. ${ }^{2}$ Melalui teori ini, Said menegaskan, para sarjana Eropa kerapkali bias dan bahkan keliru dalam menafsirkan khazanah peradaban Asia, Timur Tengah, dan Afrika sehingga melahirkan kontradiksi-kontradiksi historis yang semata mengunggulkan supremasi khazanah dan diskursus barat sendiri. ${ }^{3}$

Edward Said dan para ahli teori poskolonial menulis, ${ }^{4}$ selama ini sarjana barat kerap menggambarkan peradaban dan kebudayaan non-barat secara bias dan kurang akurat, baik dalam literatur, seni, pendidikan dan masyarakat, sembari mengabaikan kekayaaan khazanah dan keragaman budaya. Alih-alih menghargai dan menghormati, tradisi non-barat selalu dicitrakan dan distigmatisasi dengan karakter-karakter pejoratif semisal mistik, eksotik, identikal satu dengan lainnya, berbahaya, dan lebih parah lagi menilainya sebagai 'liyan' (the others), yang total berbeda dengan 'kami' (the us) dan jauh 'berbeda' dengan superioritas budaya dan peradaban barat. $^{5}$

Ironisnya, dalam amatan Edward Said, fenomena ini sangat berkebalikan dengan "perhatian" sarjana barat yang "sangat detil" dalam menilai keragaman budaya mereka sendiri. Melalui penilaian sarjana barat yang sangat bias, simplistik dan cenderung "picik" tersebut, para "elit politik" Eropa membuat kebijakan yang makin menegaskan superioritas kebudayaaan dan peradaban mereka sebagai satu-satunya yang unggul dan

\footnotetext{
${ }^{1}$ Edward W. Said, Orientalism, (London: Penguin Books, 1978), h. 2.

${ }^{2}$ Partha Chatterjee, Rey Chow, Chinua Achebe, Homi Bhabha, Buchi Emecheta, Frantz Fanon, Jamaica Kincaid, Wole Soyinka, Gayatri Chakravorty Spivak, dan beberapa lainnya. Patick William., Laura Chrisman (Eds.), Colonial Discourse and Post-Colonial Theory: A Reader, (London and New York: Routledge Taylor \& Francis Group, 2013), 36, 66, h. 112.

${ }^{3}$ Edward W. Said, Orientalism, (London: Penguin Books, 1978), h. 3.

${ }^{4}$ Patick William., Laura Chrisman (Eds.), Colonial Discourse and Post-Colonial Theory, h. $132,428,498$.

${ }^{5}$ Edward W. Said, Orientalism, h. 1-3, dan 249-250.
} 
menilai kebudayaan 'liyan' sebagai yang rendah (inferior). ${ }^{6}$ Akibatnya, perspektif 'eurosentrisme' ini berkontribusi pada bentuk-bentuk diskriminasi, ketidakramahan dan bahkan sikap permusuhan terhadap kebudayaan dan peradaban "liyan", termasuk umat Islam (pen: islamophobia). ${ }^{7}$ Dalam kesimpulan Akoff, eurosentrisme adalah "epistemologi ketidakpedulian" (epistemology of ignorance). ${ }^{8}$

Dalam menganalisa diskursus orientalis atas Wahhabisme, penulis merujuk empat (4) kategorisasi Said tentang agenda "kuasa" dalam diskursus orientalis: kuasa-politik dengan agenda proyek kolonialisasi dan imperalisasi; kuasa-pengetahuan melalui iming-iming science dan pengetahuan lainnya terhadap Timur; kuasa-kultural melalui kanonisasi teks, pembudayaan nilai dan estetika Barat sehingga Timur mengadopsi nilai dan estetika kolonial, seperti dalalm kasus India, Mesir dan negara bekas koloni lain; kuasa-moral melalui penanaman "yang baik" dan "yang buruk" bagi Timur. ${ }^{9}$

Perspektif poskolonial ini penulis manfaatkan untuk melihat sejauhmana relasi kuasa diskursif sejak kemunculan Wahhabisme di dalam berbagai sumber yang bisa jadi saling menguatkan atau juga saling bertolakbelakang, tentu dalam konteks dan ruang kolonialisme barat di Jazirah Arab masa itu. Penulis melihat, keberhasilan "kuasa dan ideologi" Wahhabisme sehingga berhasil mengokupasi Hijäz dan Jazirah Arab tak terlepas dari episteme-episteme dan momen-momen penting kolonial. ${ }^{10}$

Berdasarkan kerangka ini, penulis meninjau sumber-sumber tentang Muhammad bin 'Abd al-Wahhāb dan menemukan setidaknya terdapat tiga otoritas epistemis-diskursif, yakni sumber-sumber salafī-wahhābī, orientalis, dan sunni-mazhabì. Sumber-sumber salafí-wahhābì merujuk pada karyakarya para ideolog, aktifis dan simpatisan gerakan ini, penulis kategorikan sebagai blok "loyalis". Sumber-sumber orientalis mengacu pada karya-karya sarjana, petualang barat, serta aparat negara yang menjelajah atau

${ }^{6}$ Edward W. Said, Orientalism, h. 14, dan 108-109.

${ }^{7}$ Edward W. Said, Orientalism, h. 27.

${ }^{8}$ Linda Martin Akoff, "Philoshophy and Philosophical Practice: Eurocentrism as an Epistemology of Ignorance", dalam James Kids, Jose Medina, Gaile Pohlhaus, (Eds.), The Routledge Handbook of Epistemic Injustice, (London \& New York: Routledge Taylor \& Francis Group, 2017), h. 397-406.

${ }^{9}$ Edward W. Said, Orientalism, h. 12, 123.

10 William Ochsenwald, Religion, Society and the State in Arabia: The Hijaz under Ottoman Control 1840-1908, (Columbus: Ohio State University Press, 1984), h. 3-10, 131152. Imran N. Hosein, The Caliphate, The Hejaz and The Saudi Wahhabi Nation State, (New York: Masjid Dar al-Quran, 1996), h. 14-27. 
"bertugas" di Jazirah Arab masa itu. Sumber-sumber sunnī-mazhabī merepresentasikan karya-karya ulama, sarjana dan cendikiawan yang secara kritis melakukan eksmaninasi, kritik teologis serta menolak ajaran dan doktrin Muḥammad bin 'Abd al-Wahhāb sejak awal kemunculan hingga kekinian, penulis sebut barisan terakhir ini sebagai "kritikus".

\section{Diskursus Para Loyalis (Salafi-Wahhābī) Lintas Negara}

Muhammad bin 'Abd al-Wahhāb (1703-1792M) mulai menyebarluaskan ajaran melalui kitab induknya paling awal berjudul Kitāb al-Tawhìd alladhi Huwa Haqq Allah 'alà al-'Abìd dan beberapa kitab lainnya yang memuat doktrin dan pemahaman sang pendiri Wahhabisme, antara lain: konsep tăghūt, pembatal keimanan (nawāqị̣ al-īmān wa al-islām), tawhid pengkafiran (tawhid takfiri), anti-mazhab (alla-madzhabiyyah), antitaklid, jihad perang (qitāl), al-wal'̄' wa al-barā', anti pada pembagian bid'ah dan beberapa lainnya. ${ }^{11}$ Penulis tidak mengurai secara detil argumentasi teologis dan penjelasan rinci setiap konsep, sebab fokus paper ini adalah diskursus para loyalis tentang sang tokoh.

Sumber-sumber induk salafí-Wahhäbis memposisikan sang tokoh Muḥammad bin 'Abd al-Wahhāb (1703-1792M) dan gerakan Wahhabismenya sebagai tokoh atau gerakan pembaharuan, modernisasi, pemurnian, reformasi keagamaan, dan bahkan menarasikan sang tokoh setara dengan imām mujtahid empat mazhab. Diskursus dan narasi ini terserak dalam berbagai karya para ideolog awal, aktivis dan simpatisan hingga konteks kekinian. Diskursus ini penulis temukan misalnya dalam sumber-sumber wahhabisme awal anggitan anak cucu sang pendiri, populer di Saudi Arabia dengan gelar $\bar{A} \bar{l} \bar{u}$ al-Shaikh, khususnya dua cucu pendiri Wahhabisme bernama Sulaimān bin 'Abd Allāh bin Muhammad bin 'Abd al-Wahhāb (1785-

${ }_{11}$ Muḥammad bin 'Abd Al-Wahhāb, Kitāb al-Tawḥìd alladhì Huwa Haqq Allāh 'alā al'Abìd, (Beirüt: Manshürāt Dār Maktabah al-Hayāt, 1390H/1970M). Muhammad bin 'Abd AlWahhāb, Masāil al-Jāhiliyyah allatì Khālafa Fìhà Rasūl Allāh Salla Allà̄h 'Alaihi wa Sallama

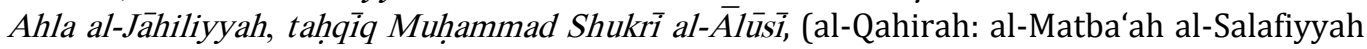
wa Maktabataha, 1436H). Muhammad bin 'Abd Al-Wahhāb, Kashf al-Shubhāt, Cet. Ke-1, (Dār 'Umar bin al-Khaț̣āb, 1430H/2009M). Muhammad bin 'Abd Al-Wahhāb, Mufíd al-Mustafĩd Fï Kufri Tārik al-Tawhịid, Cet. Ke-1, (al-Dawlah al-Islāmiyyah Khilāfah 'alā Manhaj alNubuwwah: Maktabah al-Himmah, 1436H). 
1818M),12 dan 'Abd al-Raḥmān bin Ḥasan bin Muḥammad bin 'Abd al-Wahhāb $(1779-1869 \mathrm{M}) \cdot{ }^{13}$

Senada dengan cucu pendiri, blok loyalis wahhābī jalur non-Ālū alShaikh dalam karya-karya mereka juga mengajukan diskursus yang sama persis, termasuk sejarawan paling awal Ibnu Ghannām (w. 1811M) dalam kitab Tärikk Najd: Rawḍah al-Afkār wa al-Afhām li Murtād Ḥàl al-Imām wa Ti'dād Ghazawāt Dhawī al-Islām terdiri dari 2 jilid;14 Ibnu Bishr (17801871M) dalam kitab Unwān al-Majd Fī Tärīkh Najd, ${ }^{15}$ dan berbagai karya lain. Dalam perkembangannya, diskursus para ideolog wahhabis awal ini menjelma menjadi episteme dan menjadi rujukan karya-karya para ideolog dan simpatisan generasi berikutnya.

Konstruk diskursus serupa juga penulis temukan dalam karya ideolog wahhābi jalur non-Ālū al-Syaikh generasi berikutnya yang notabene merupakan murid-murid ideolog $\bar{A} l \bar{u}$ al-Shaikh di atas, antara lain Sulaimān bin Sạ̣mān (1850-1931M) dalam kitab Al-Hadiyyah al-Saniyyah wa alTuhfah al-Wahhābiyyah al-Najdiyyah; ${ }^{16}$ atau ideolog wahhabi generasi berikutnya seperti 'Abd al-'Aziz bin Bāz (1990-1999M) dalam kitab AlImām Muhammad bin 'Abd al-Wahhāb Da'watuh wa Sïratuh, ${ }^{17}$ atau Șālih al'Uthaimin (1929-2001M) dalam dua kitabnya Al-Shaikh Muhammad bin 'Abd al-Wahhāb Hayātuh Wa Fikruh. ${ }^{18}$

Diskursus serupa dengan para loyalis di atas juga penulis temukan dalam karya-karya ideolog salafí-Wahhābi kekinian, termasuk Rabi' bin Hādi

12 Sulaimān bin 'Abd Allāh bin Muhammad bin 'Abd al-Wahhāb, Al-Dalāil fi Hukm Muwālāh Ahl al-Ishrāk wa Awthaq 'Urā al-İmān, Cet. Ke-1, (Irāq: Maktabah al-Himmah-alDawlah al-Islāmiyyah 'ala Minhaj al-Nubuwwah, 1436H), h. 3-76.

13 'Abd al-Raḥmān bin Hasan bin Muhammad bin 'Abd al-Wahhāb, Fath al-Majīd li Sharḥ Kitāb al-Tawhịd, taḥqī al-Walid bin 'Abd al-Raḥmān bin Muḥammad Ālū Fariyyān, Cet. Ke-8, (Riyāḍ: Dār al-Muayyad, 1423H/2002M), h. 7-672. 'Abd al-Raḥmān bin Ḥasan bin Muhammad bin 'Abd al-Wahhāb, Qurrah 'Uyūn al-Muwaḥhidìn, taḥqiq Sa'īd bin Naṣr Sayyid Muḥammad, (Riyāḍ: Maktabah al-Rushd, 1421H), h. 2-362.

${ }^{14}$ Husain bin Abū Bakar bin Ghannām, Rawḍh al-Afkār wa al-Afhām li Murtād Hāl alImām wa Ti'dād Ghazawāt Dhawī al-Islām, taḥqì Nāṣir al-Dīn al-Asad, Cet. Ke-4, (Beirut: Dār al-Shurūq, 1415H/1994M),

15 'Uthmān bin 'Abd Allāh bin Bishr, 'Unwān al-Majdi Fī Tārikhi Najd, tahqīiq 'Abd alRaḥmān bin 'Abd al-Lațîf Ầū al-Shaykh, Cet. Ke-4, (Riyāḍ: Dārah al-Malik 'Ảbd al-‘Azìz, 1402H/1982M).

16 Sulaimān bin Saḥmān, Al-Hadiyyah al-Saniyyah wa al-Tuhfah al-Wahhābiyyah alNajdiyyah, Cet. Ke-1, (Mișrā: Maṭba'ah al-Manār, 1342H), h. 4-6.

17 'Abd al-'Azìz bin Bāz, Al-Imām Muhammad bin 'Abd al-Wahhāb Da'watuh wa Siratuh, Cet. Ke-2, (Riyāḍ: al-Riāsah al-'Āmmah, 1411H), h. 5-61.

18 Șālih al-'Uthaimīn, Al-Shaikh Muḥammad bin 'Abd al-Wahhāb Hayātuh Wa Fikruh, (Riyāụ: Dằr al-'Ulum, 1416H), h. 9-160.

Jurnal Tashwirul Afkar Vol. 38, No. 01, Tahun 2020. 
al-Madkhali (1931-sekarang) di Arab Saudi dalam kitab al-Firqah al-Nājiyyah Ușüluhā wa 'Aqā'iduhāa,19 'Abd al-Raḥmān bin Nasir al-Barrāk (1933sekarang) di Saudi Arabia dalam ketiga kitabnya Sharh al-Ușul al-Thaläthah Li al-Imām al-Mujaddid Muhammad bin 'Abd al-Wahhāb,' ${ }^{20}$ kitab Sharh al'Aqīdah a-Tahāwiyyah,'11 dan kitab Sharh Nawāqị̣ al-İmān Li al-Imām alMujaddid Muhammad bin 'Abd al-Wahhāb;'22 serta para ideolog salafí-Wahhābī di Saudi Arabia lintas generasi lainnya.

Dari luar Saudi Arabia, konstruksi diskursif serupa juga penulis temukan dalam karya-karya ideolog, aktivis dan simpatisan wahhabisme, termasuk: Muḥammad Nạșir al-Dīn al-Albāni (1914-1999M) di Yordania dalam kitab ;23 Muqbil bin Hādi al-Wadi`i (1933-2001M) di Yaman dalam kitab ;24 Mahmud Shukrī al-Ālūsì (1856-1924M) di Irak; ${ }^{25}$ Muhammad Rashìd Riḍa (1865-1935M) di Mesir;26 Muhammad Ḥāmid al-Fiqii (1892-1959M) di Mesir;27 Maḥmūd Muḥammad Shākir (1892-1958); ${ }^{28}$ Ṭahā Ḥusain (18891973) di Mesir;"29 Muhammad Khalil Harrās (1916-1975M) Mesir, ${ }^{30}$ dan beberapa lainnya.

${ }^{19}$ Rabī' bin Hāđì al-MadkhaTi, al-Firqah al-Nājiyyah Ușūluhā wa 'Aqā'iduhā, Cet. Ke-1, (al-Jazāir: al-Mirāth al-Nabawīi, 2009M), h. 7-56. Rabī' bin Hāđdì al-Madkhali, Sadd 'Udwān alMulḥidīn wa Hukm al-Istì ānah 'alā Qitālihim bi Ghair al-Muslimīn, Cet. Ke-1, (Riyāḍ: alFurqān, 1411H), h. 5-91.

20 'Abd al-Raḥmān bin Nāṣir al-Barrāk, Sharh al-Ușūl al-Thalāthah Li al-Imām alMujaddid Muhammad bin 'Abd al-Wahhāb, tarji' 'Abd al-Raḥmān bin Ṣālị̣ al-Sudais, (Riyāạ: Muassasah Sabkah Nūr al-Islām, 1424H), h. 5-53.

21 'Abd al-Raḥmān bin Nāṣir al-Barrāk, Sharḥ al- 'Aqīidah a-Ṭahāwiyyah, taḥīi 'Abd alRaḥmān bin Șālih al-Sudais, Cet. Ke-1, (Riyāḍ: Dār al-Tadmīriyyah, 1429H/2008M), h. 12-18.

22 'Abd al-Rahmān bin Nāṣir al-Barrāk, Sharh Nawāqị̣ al-Īmān Li al-Imām al-Mujaddid Muhammad bin 'Abd al-Wahhāb, tarji' 'Abd al-Rahmān bin Ṣālih al-Sudais, (Riyāḍ: Muassasah Sabkah Nūr al-Islām, 1424H), h. 5-47.

23 Hani Nasira, "Salafist Challenge al-Azhar for Ideological Supremcy in Egypt", Terrorism Monitor, Vol III, Issue 35, (September 212, 2010), h. 7-9.

${ }^{24}$ Muqbil bin Hādi al-Wadi'i, Hādihi Da' watunā Wa 'Aqìdatunā, Cet. Ke-2, (Yaman: Dār al-Āthar, 1429H/2008M), h. 3-18.

25 Maḥmūd Shukrī al-Ālūsì, Târỉkh Najd al-Hadith, tahqīiq Muhammad Bahjah al-Atharī, Cet. Ke-3, (Baghdād: Dār al-'Alim li al-Nashr, 1415H/1929M), h. 80-111.

${ }^{26}$ Muhammad Rashīd Rị̣ā, Al-Wahhābiyyūn wa al-Hijāz, Cet. Ke-1, (Miṣrā: Maṭba'ah al-Manār, 1344H), h. 6-10.

${ }^{27}$ Muhammad Ḥāmid al-Fiqī, Azhār min Riyāụ: Sirah al-Imām al-'Ādil 'Abd al-'Azīs bin 'Abd al-Raḥmān al-Faișal Ālu Su' ùd, tahqīiq 'Uthmān al-Mișrī, Cet. Ke-1, (Riyad: Maktabah alMawrid, 1429H/2008M), h. 23-36.

${ }^{28}$ Maḥmūd Muḥammad Shākir, Hukm al-Jāhiliyyah, (Riyāḍ: Maktabah al-Sunnah, 1991), h. 25-60.

29 Ṭahā Husain, Al-Hayāt al-Adabiyyah Fī Jazīrah al-'Arab, Cet. Ke-1, (Damshiq: Maktab al-Nashr al-'Arabi, 1354H/1925M), h. 22-51. 
Mayoritas blok loyalis di atas secara silih berganti menyematkan label kepada Muhammad bin 'Abd al-Wahhāb dan Wahhabisme-nya sebagai tokoh pembaharu (al-mujaddid), penggerak modernisasi (al-muharrik alhadithiyyah), tokoh purifikasi (al-qā'id li al-tasfiyyah), tokoh gerakan reformasi keislamaan (al-harakah al-iṣlāhiyyah al-islämiyyah) dan label-label lainnya. Muncul pertanyaan, bagaimana respon kaum sunni-mazhabi generasi awal hingga periode kontemporer saat ini atas kampanye Muhammad bin 'Abd al-Wahhäb dengan ajaran Wahhabisme-nya?

\section{Diskursus Para Kritikus (Sunni-Mazhabï)Lintas Negara}

Penulis menemukan, sejarah kritik dan penolakan atas ideologi Wahhabisme atau varian barunya ini, populer disebut salafí dan salafí-jihādi, telah berlangsung ratusan tahun dan bahkan bermula sejak pertama kali sang pendiri Muhammad bin 'Abd al-Wahhāb mulai menyebarluaskan ajarannya di Najd melalui kitabnya Kitāb al-Tawhịd alladhi Huwa Haqq Allah 'alā al-'Abijd dan beberapa kitab lainnya yang memuat doktrin dan pemahaman ekstrim, antara lain konsep tăghüt, pembatal keimanan (nawāqị̣ al-īmān wa al-islām), tawhid pengkafiran (tawhid takfïri), antimazhab (alla-madzhabiyyah), anti-taklid, jihad perang (qitāl), al-walā' wa albarā', anti pada pembagian bid'ah dan seterusnya. ${ }^{31}$

Merespon ajaran Wahabisme ini, para sarjana, intelektual dan ulama kritis dari barisan sunni-mazhabi (ideolog, aktifis dan simpatisan) melakukan eksaminasi teologis-ideologis dan pada akhirnya menentang Muhammad bin 'Abd al-Wahhāb dan Wahhabisme-nya sejak awal. Kritikus dan penentang paling awal justru berasal dari keluarganya sendiri yang notabene merupakan para pemuka mazhab Hanbali di Najd, yakni sang ayah 'Abd al-Wahhāb bin Sulaimān selaku Qāọi (Hakim) 'Uyainah bermazhab Ḥanbali dan sang kakak Sulaimān bin 'Abd al-Wahhāb yang juga Qāọi wilayah Huraimilā’’ bermazhab Ḥanbali dalam kitab al-Sawā iq al-Ilāhiyyah Fỉ al-Radd

30 Muḥammad Khalil Harās, Al-Harakah al-Wahhābiyyah: Raddun 'alā Maqāl li alDuktūr Muḥammad al-Bahī Fī Naqd al-Wahhābiyyah, (Beirut: Dar al-Katib al-'Arabì, 1410H), h. 11-80.

${ }^{31}$ Muhammad bin 'Abd Al-Wahhāb, Kitāb al-Tawhìd alladhì Huwa Haqq Allāh 'alā al'Abìd, (Beirūt: Manshūrāt Dār Maktabah al-Ḥayāt, 1390H/1970M). Muhammad bin 'Abd AlWahhāb, Masāil al-Jāhiliyyah allatī Khàlafa Fìhā Rasūl Allāh Salla Allà̄h 'Alaihi wa Sallama Ahla al-Jāhiliyyah, taḥiq Muhammad Shukrī al-Ālūsi, (al-Qahirah: al-Matba'ah al-Salafiyyah wa Maktabataha, 1436H). Muhammad bin 'Abd Al-Wahhāb, Kashf al-Shubhāt, Cet. Ke-1, (Dār 'Umar bin al-Khațtāb, 1430H/2009M). Muhammad bin 'Abd Al-Wahhāb, Mufíd al-Mustafīd Fì Kufri Tārik al-Tawhịd, Cet. Ke-1, (al-Dawlah al-Islāmiyyah Khilāfah 'alā Manhaj alNubuwwah: Maktabah al-Himmah, 1436H).

Jurnal Tashwirul Afkar Vol. 38, No. 01, Tahun 2020. 
'alā al-Wahhābiyyah, ${ }^{32}$ atau Faṣl al-Khițāb min Kitābi Allāh wa al-Hadithi alRasūl wa Kalāmi al-Ulamā' Fì Madhhabi Muhammad bin 'Abd al-Wahhāb. ${ }^{33}$

Selain penolakan dari keluarga, kritik atas Wahhabisme juga disajikan para ideolog mazhab Ḥanbali semasa, termasuk Shaikh al-Faqih Muhammad bin 'Abd al-Raḥmān bin 'Afāliq al-Ḥanbali (1689-1751M); Shaikh al-Faqīh Muhammad bin Aḥmad bin 'Ali bin Sahịm al-Hanbali (1744M); Shaikh alFaqih Sulaimān bin Muhammad bin Saḥim bin Ahmad bin Saḥim al-Ḥanbali (1767-1815M); al-Faqīh Ḥuraimilā' Imām 'Abd Allāh bin 'Isā al-Muwaisì alTamimi al-Ḥanbali (1762M), dan empat puluh satu (41) ulama Hanbali lainnya yang hidup semasa dan mereka yang berdekatan secara periodik. ${ }^{34}$

Kritik dan penolakan atas Wahhabisme, termasuk ketidaksesuaiannya dengan ajaran dan manhaj Salaf al-Șālih juga terekam dalam beberapa karya para ulama-ulama lintas mazhab (ideolog) yang hidup semasa dengan Muhammad bin 'Abd al-Wahhāb sendiri, antara lain Muḥammad bin Sulaimān

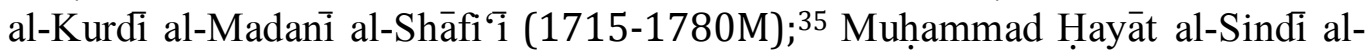
Madani al-Ḥanafî $(1750 \mathrm{M})$; dan 'Abd Allāh bin Ibrāhīm bin Saif al-Najdì alHanbali $(1775 \mathrm{M}),{ }^{36}$ termasuk "guru-guru" lainnya yang penulis urai dalam artikel tersendiri.

Selain para ulama Ḥanbali, kritik dan penolakan atas wahhabisme serta eksaminasi teologis yang menetapkan ketidaksesuaian wahhabisme dengan ajaran dan manhaj salaf al-șālih juga terekam dalam beberapa karya ulama lintas mazhab yang hidup semasa dengan Muhammad bin 'Abd al-Wahhāb sendiri, antara lain Muhammad bin Sulaimān al-Kurdì al-Madanì al-Shāfi ' $\overline{\mathrm{i}}$ (1715-1780M); ${ }^{37}$ Muhammad Ḥayāt al-Sindi al-Madanì al-Ḥanafí (w. 1750 M). ${ }^{38}$ Ironisnya, kedua tokoh sunni-mazhabi kritikus gigih wahhabisme ini

32 Sulaimān bin 'Abd al-Wahhāb, al-Sawā'iq al-Ilāhiyyah Fì al-Radd 'alā alWahhābiyyah, Cet. Ke-3, (Istanbūl-Turki: Ikhlās Wavki Yayindir, 1399H/1979M). Sulaimān bin 'Abd al-Wahhāb, Faṣl al-Khițāb min Kitābi Allāh wa al-Hadithi al-Rasūl wa Kalāmi alUlamā' Fì Madhhabi Muhammad bin 'Abd al-Wahhāb, Cet. Ke-3, (Istanbūl-Turkì: Maktabah 'Ishiq Kitabevi, 1399H).

${ }^{33}$ Sulaimān bin 'Abd al-Wahhāb, Fașl al-Khitāà min Kitābi Allāh wa al-Hadithi al-Rasūl wa Kalāmi al-Ulamā' Fì Madhhabi Muhammad bin 'Abd al-Wahhāb, Cet. Ke-3, (Istanbūl-Turkì: Maktabah 'Ishiq Kitabevi, 1399H).

${ }^{34}$ Muṣtafā Ḥamdūn 'Ilyān al-Ḥanbali, Al-Hanābilah wa al-Ikhtilāf ma'a al-Salafiyyah alMu'ạsirah Fì al- 'Aqāid wa al-Fiqh wa al-Tasawwuf, (Dār al-Nūr al-Mubīn, 2014M), h. 133.

35 Sayyid Aḥmad Zainī Dahlān, al-Durar al-Saniyyah Fì al-Radd 'alā al-Wahhābiyyah, ta' $n \bar{i}^{`}$ Jibrīl Haddād, Cet. Ke-1, (Dimashqì: Maktabah al-Aḥbāb wa Dār Ghār Hirā', 1424H/2003M), h. 112.

${ }^{36}$ Sayyid Aḥmad Zainī Daḥlān, al-Durar al-Saniyyah, h. 112.

${ }^{37}$ Sayyid Aḥmad Zainī Daḥlān, al-Durar al-Saniyyah, h. 112.

${ }^{38}$ Sayyid Ạ̣mad Zainī Daḥlān, al-Durar al-Saniyyah, h. 112. 
justru "dinilai" oleh sebagian orientalis sebagai tokoh-tokoh yang "menginspirasi" sikap ekstrimisme Muhammad bin "Abd al-Wahhāb dan selama ratusan tahun, hipotesis ini direplikasi secara taken for granted oleh para sejarawan loyalis wahhabi dan mayoritas sarjana barat. ${ }^{39}$

Selain penolakan dari ulama lintas mazhab semasa, kritik dan penolakan atas wahhabisme juga dianggit para ulama dan sejarawan sunnimazhabi generasi berikutnya, termasuk sejarawan Ibnu Ḥumaid al-Najdi alHanbali (1821-1878M) mufti dan sejarawan Mekkah bermazhab Hanbali terakhir dalam kitab al-Suhub al-Wābilah 'alā Darā'ị̣ al-Hanābilah, ${ }^{40}$ Mufti Mekkah bermazhab Shāfi ‘ terakhir sekaligus sejarawan Muslim Sayyid Aḥmad Zainī Daḥlān al-Shāfíi al-Asy'arì (1816-1887M) dalam tiga kitab anggitannya berjudul Khulāsah al-Kalām Fì Bayāni Umarā' al-Bilād al-Harām, al-Durar al-Saniyyah fì al-Radd 'alā al-Wahhābiyyah, Fitnah Wahhābiyyah,, ${ }^{41}$ Syaikh Yūsuf bin Ismā'îl al-Nabhāni al-Shāfíi al-Asy'ari (1841-1932M) dalam kitab Syawāhidu al-Haq fì al-Istighāthah bi Sayyid al-Khalqi Salla Allāh 'Alaih Wa Sallam.42 Penting dicatat, sebagian besar sanad Ulama Nusantara "bersambung" dengan Sayyid Aḥmad Zainī Daḥlān, termasuk sanad keilmuan Hadhratus Syaikh KH Hasyim Asy'ari, Pendiri sekaligus Rais Akbar Jamiyyah Nahdhatul Ulama (NU).

Di Indonesia, ulama yang secara spesifik menulis kritik penolakan atas ideologi wahhabisme cukup banyak. Akan tetapi, mengingat keterbatasan, penulis cukup mengulas kritik dan penolakan dua tokoh penting dalam silsilah sanad keilmuan Ulama Nusantara, yakni Hadratus Syaikh KH. Muhammad Hasyim Asha'ri al-Shafi'i al-Ash'ari selaku pendiri Nahdhatul Ulama dalam kitabnya Risālah Ahl al-Sunnah wa al-Jamā'ah dan KH. Faqih Maskumambang al-Shafi'i al-Ash'ari sebagai wakil Sang Rais Akbar dalam kitabnya al-Nuṣuṣ al-Islāmiyyah fí al-Radd 'ala Mazhab al-Wahhābiyyah beserta.

${ }^{39}$ Henri Laoust, "Ibn 'Abd al-Wahhab", dalam B. Lewis, VL. Menage, CH. Pellat, Joseph Schacht (eds). The Encyclopaedia of Islam: New Edition, Volume III, H-IRAM, (Leiden: E.J Brill and London: Luzac \& Co., 1986), h. 677.

40 Muhammad bin 'Abd Allāh bin Ḥumaid al-Najdi al-Ḥanbali, Al-Suhub al-Wābilah 'alā Darā'iḥa al-Ḥanābilah, (Makkah: Maṭba'ah al-Imām Aḥmad, 1416H/1996M), h. 275-277.

${ }^{41}$ Sayyid Aḥmad Zainī Dahlān, Khulāṣah al-Kalām Fỉ Bayāni Umarā' al-Bilād al-Harām, taḥqiq Muhammad Fārish al-Shāfíc 'i al-Qāhirīi, (Mekkah: Maṭba'ah Arḍ al-Ḥaramain, 1035H), h. 304. Sayyid Ahmad Zainī Daḥlān, al-Durar al-Saniyyah, 8-136. Sayyid Aḥmad Zainī Daḥlān, Fitnah Wahhābiyyah, (Istānbūl-Turkì: Darussefaka, Isik Kitabevi, 1978M), h. 4.

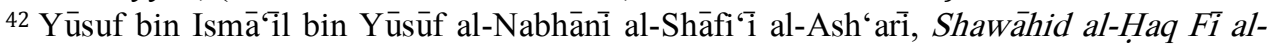
Istighāthah Bi Sayyid al-Khalq Salla Allāh 'Alaih Wa Sallam, taṣịih 'Abd alWārith Muhammad 'Aili, Cet. Ke-3, (Beirūt: Dār al-Kutub al-'Ilmiyyah, 1428H/2008M), h. 4244.

Jurnal Tashwirul Afkar Vol. 38, No. 01, Tahun 2020. 
Hadratus Syaikh KH. Muhammad Hasyim Asha'ri al-Shafi'i al-Ash'ari dalam kitab Risālah Ahl al-Sunnah wa al-Jamā'ah fi Hadith al-Mawtā wa Ashrāt al-Sä̀ah wa Bayāni Mafhümi al-Sunnah wa al-Bid'ah melakukan eksaminasi atas gagasan keagamaan yang dianggit Muhammad 'Abduh dan Rashid Ridha. KH Hasyim Asy'ari menulis, gerakan 'Abduh dan Ridha di Mesir adalah penerus gerakan bid'ah Muhammad bin 'Abd al-Wahhāb dengan wahhabisme-nya. Selain kepada Muhammad bin 'Abd al-Wahhāb, kritik teologis KH. Hasyim Asyari juga dialamatkan kepada Ibnu Taimiyyah, Ibnu Qayyim al-Jawziyyah dan Ibnu 'Abd al-Hadi, khususnya terkait dengan fatwa Ibnu Taimiyyah dan koleganya tentang keharaman seorang muslim ziarah ke makam Nabi Muhammad SAW.43 Begitu juga, KH. Muhammad Faqih Maskumambang dari Gresik dalam kitab al-Nusuus al-Islämiyyah Fỉ alRadd 'alā al-Wahhäbiyyah juga menentang ideologi dan ajaran wahhabisme ketika merespon gagasan pembaharuan Jamāl al-Dīn al-Afghāni, Muhammad 'Abduh dan Rashìd Rị̣a, dan menilai ketiga sebagai simpatisan wahhabisme. ${ }^{44}$

Visi geo-politik atas dinamika dan perubahan praktek keagamaan di Jazirah Arab mendorong KH. Hasyim Ash'ari, KH. Faqih Maskumambang dan para ulama masa itu untuk membentuk Komite Hijaz yang diketuai KH. Wahab Hasbullah mewakili jejaring Ulama Nusantara untuk menemui dan melobi Raja 'Abd al-'Azīs al-Sa'ūd dengan lima permohonan. Salah satunya adalah permohonan untuk membatalkan rencana pembongkaran makam Nabi Muhammad Saw atas desakan sekutu wahhabi-nya. Komite Hijäz ini sekaligus menjadi salah satu latarbelakang pembentukan organisasi Nahdhatul Ulama secara formal pada 31 Januari 1926. Dari lima (5) permohonan, hanya satu yang diterima, yakni menerima usulan Komite Hijaz untuk membatalkan rencana pembongkaran Makan Nabi Muhammad Saw. 45

Mencermati mata rantai kritik dan penolakan kaum sunni-mazhabi atas wahhabisme, meskipun berbeda secara periode, namun sanad dan manhaj jejaring ideologi kaum sunni-mazhabīini, atau dalam konteks Indonesia

${ }^{43}$ Haḍrah al-Shaikh Muhammad Hāshim Ash'arī, Risālah Ahl al-Sunnah wa al-Jamā‘ah Fi Hadith al-Mawtā wa Ashrät al-Sā'ah wa Bayāni Mafhūm al-Sunnah wa al-Bid'ah, tahqi iqq Muhammad 'Ișām Ḥādiq, Cet. Ke-1, (Tebuireng: Aswaja al-I'lāmì, 1418H), h. 12-23.

${ }^{44}$ Muḥammad Faqīh bin 'Abd al-Jabbār al-Maskūmamābānī, Al-Nuṣuṣ al-Islāmiyyah Fì al-Radd 'alā Madhhab al-Wahhābiyyah, taqrīz wa takhrīj Shaikh Maimūn Zubair dan Shaikh 'Abd al-'Azìis Mashhūri, (Bogor: Șahịifah Li al-Ṭibā'ah wa al-Nashr, 1436H/2015M), h. 102111.

45 "Piagam Komite Hijaz", dalam Pengurus Besar Nahdlatul Ulama (PBNU), Ensiklopedi Nahdlatul Ulama: Sejarah, Tokoh dan Khazanah Pesantren, Jilid 1, (Jakarta Pusat: Mata Bangsa dan PBNU, 2013), h. 233. 
mewujud dalam Jejaring Islam Nusantara, sejak awal merupakan jejaring kritikus paling gigih dan penentang keras atas wahhabisme berdasarkan manhaj salaf al-sălih atau faham ahl al-sunnah wa al-jamā'ah. Jejaring sunnīmazhabi ini merupakan mata rantai tak terpisahkan dan saling menguatkan, baik secara 'aqīdah, fiqh dan siyāsah. Di Indonesia, arus ini dalam perkembangannya bertransformasi menjadi sebuah episteme pengetahuan dan kebudayaan dengan jargon Islam Nusantara yang berbasis pada keseimbangan pola relasi ukhuwwah islamiyyah (teologi, fiqh, siyasah, tasawwuf); ukhuwwah wataniyyah (tsaqāfah dan hadharah), dan ukhuwwah bashariyyah (kewarganegaraan setara).

Dalam konteks paling mutakhir, kritik dan penolakan atas wahhabisme dengan berbagai identitas "varian" turunan barunya yang mengidentifikasi diri dengan gerakan salafisme (al-salafiyyah) hingga salafí-jihädi tidak berhenti dan terus berlanjut hingga generasi sunni-mazhabi kontemporer, antara lain: Syaikh Ramaḍan al-Būți al-Shāfi' ${ }^{\prime}$ al-Ash'ari (1929-2013M) dalam tiga kitabnya al-Salafiyyah Marhalah Zamāniyyah Mubārakah La Mazhabun Islāmiyyun, ${ }^{46}$ al-Lāmazhabiyyah Akhtar Bid'atin Tuhaddidu alSharī'ah al-Islämiyyah, ${ }^{47}$ al-Jihäd fì al-Isläm Kaifa Nafhamuhu wa Kaifa Numārisuhu,48 Syaikh 'Ali Jum'ah al-Shāfi'i al-Ash'arī (1952-sekarang) dalam kitab al-Bayān limā Yusghil al-Adzhān al-Juz al-Ūlā wa al-Thānīi, alBayān al-Qawìm li Taṣhịh Ba'ḍ al-Mafähìm, ${ }^{50}$ al-Mutashaddidun Manhajuhum wa Munāqashat Ahhami Qadāyāhum. ${ }^{51}$

Kritik dan penolakan atas wahhabisme atau salafisme juga diajukan Syaikh al-Azhar Ahmad Muḥammad Aḥmad al-Ṭayyib al-Ḥanafí al-Ash'arì alMātūridi (1946-sekarang) dalam makalah Man Hum Ahl al-Sunnah wa al-

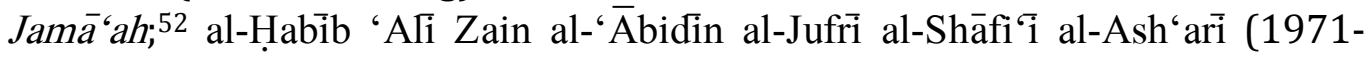

46 Ramadhan al-Būțì al-Shāfi'ì al-Ash'arì, Al-Salafiyyah Marhalah Zamāniyyah Mubārakah La Mazhabun Istāmiyyun, (Dimashqi: Dār al-Fikr, 1998M), h. 241.

${ }^{47}$ Ramadhan al-Būtị al-Shāfi ‘ì al-Ash 'arì, Al-Lāmazhabiyyah Akhtar Bid 'atin Tuhaddidu al-Sharī 'ah al-Islāmiyyah, (Sūriyah: Dār al-Farābī, 1426H/2005M), h. 39-205.

48 Ramadhan al-Būṭi al-Shāfi ‘̄i al-Ash'ari, Al-Jihād fì al-Islām Kaifa Nafhamuhu wa Kaifa Numārisuhu, Cet. Ke-1, (Dimashqi: Dār al-Fikr, 1414H/1993M), h. 147-175.

49 'A İ Jum'ah al-Shāfi ‘ì al-Ash'arì, al-Bayān limā Yusghil al-Adzhān, Cet. Ke-11, al-Juz al-Ūlā, (al-Qāhirah: Dār al-Maqțam li al-Nashr wa al-Tawzi'‘, 1426H/2005M), h. 147-150.

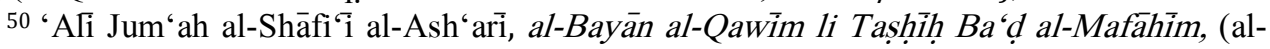
Qāhirah: Dār al-Sundus, 1428H/2007M), h. 57-63.

51 'A ATi Jum'ah al-Shāfi'‘ al-Ash'ari, al-Mutashaddidūn Manhajuhum wa Munāqashat Ahhami Qadāyāhum, Cet. Ke-1, (al-Qāhirah: Dār al-Maqțam li al-Nashr wa al-Tawzì', 1432H/2011M), h. 60-70.

52 Aḥmad Muḥammad al-Ṭayyib, Man Hum Ahl al-Sunnah wa al-Jamā'ah, dalam Mu'tamar al-Shīshān: Bayān wa Tawșîf Manhaj Ahl al-Sunnah wa al-Jamā'ah I'tiqādan wa Fiqhan wa Sulūkan, (Grozny-Chechnya, 25 Agustus 2016), h. 6-12.

Jurnal Tashwirul Afkar Vol. 38, No. 01, Tahun 2020. 
sekarang) dalam kitab Sirr al-Khușușiyyah fĩ al-Irtibät bi Khair al-Bariyyah; ${ }^{53}$ Usāmah Sayyid Mạ̣mūd Muhammad al-Azharì al-Shāfi'ī al-Ash'arī (1976sekarang) dalam kitab al-Haqq al-Mubīn fí al-Radd 'alā Man Talā'aba bi alDin; ${ }^{54}$ dan jejaring ulama sunni-mazhabi di berbagai belahan dunia Islam lainnya.

Secara ringkas, eksaminasi teologis kaum sunni-mazhabi sejak awal menetapkan, gerakan wahhabisme atau salafi secara sanad dan manhaj "berbeda" secara prinsip dengan tradisi salaf al-șālih̆, termasuk manhaj dan sanad keilmuan Aḥmad bin Ḥanbal. Bahkan, Shaikh Zainī Daḥlān sendiri secara spesifik menulis, sanad dan keilmuan wahhabisme jauh berbeda menyimpang dari sanad dan manhaj Ibnu Taimiyyah dan Ibnu Qayyim alJawziyyah sendiri, meski Shaikh Zaini Dahlān sendiri juga mengkritik beberapa fatwa dan pendapat Ibnu Taimiyyah dan koleganya.

Termasuk dalam barisan ini Shaikh Sulaimān bin 'Abd al-Wahhāb, Shaikh Dawūd Afandì al-Naqshabandi, Shaikh Sulaimān al-Kurdì al-Shāfi ${ }^{\circ}$, Shaikh Muḥammad Ḥayāt al-Sindì al-Hanafi al-Asha'ari 1-Mātūridì, dan mayoritas para pemuka mazhab Huanbali semasa maupun yang secara peridodik berdekatan. Penting penulis utarakan, karya-karya ulama sunn $\bar{i}-$ mazhabi periode juga ini menyebut ideologi dan gerakan Muhammad bin 'Abd al-Wahhāb dengan istilah al-wahhābiyyah, wahhabisme. ${ }^{55}$

Selain itu, kaum sunni-mazhabi lain juga menilai bahwa gerakan wahhabisme awal berakar pada gerakan khawārij; ${ }^{56}$ khususnya sekte sekte khawārij najdāt yang berkembang di daerah Najd yang saat ini juga disebut Riyāọ. Termasuk dalam kelompok sarjana ini antara lain Najā ạ al-Ṭāi ${ }^{-},{ }^{57}$ 'Abd Allāh al-Qaḥtāni, ${ }^{58}$ Muḥammad Jawwād Mughniyyah, ${ }^{59}$ dan 'Āmir al-

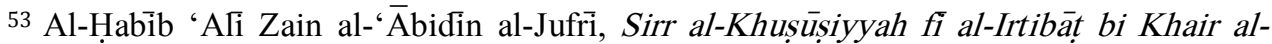
Bariyyah, taqrīz 'Umar bin Muḥammad bin Sālim bin Ḥafìu, Cet. Ke-3, (Abū Zabìi: Dār alFaqih, 1435H/2014M), h. 11-70.

54 Usāmah Sayyid Maḥmūd Muhammad al-Azharì al-Shāfi‘i al-Ash'arī, al-Haqq alMubīn fỉ al-Radd 'alā Man Talā'aba bi al-Dīn, Cet. Ke-2, (Abū Dhabì: Dār al-Faqīih li al-Nashr wa al-Tawzi', 1436H/2015M), h. 30-37.

${ }^{55}$ Sayyid Aḥmad Zainī Dạ̣lān, al-Durar al-Saniyyah, 8-136. Sayyid Aḥmad Zainī Dahlān, Fitnah, h. 4.

${ }^{56}$ Najāh al-Ṭā’ì, Al-Wahhābiyyūna Khawāriju Ummi Sanah, Cet. Ke-1, (Beirūt: Dār alMizān, 1426H/2006), 224-225. Sayyid Sharif ibnu 'Abd Allāh Sayyid Sharif, Șidqu al-Khabar Fì Khawāriji al-Qarni al-Thānī 'Ashar, (Mișrā: Maṭba'ah Kaumain al-Laẓfiyyah, 1428H/2008M), h. 160-168.

${ }^{57}$ Najāh al-Ṭà', al-Wahhābiyyūna Khawāriju, h. 224-225.

58 'Abd Allāh al-Qaḥ̣ānī, Hāulā'i Hum al-Khawārij: Ad'iyā'u al-Salafiyyah alWahhābiyyah, (Muassasah Dār Kitāb al-Islāmi: Maṭba'ah Satar, 1425H/2005M), h. 19-22. 
Kurdi, ${ }^{60}$ dan Sayyid Sharif. ${ }^{61}$ Begitu juga, Sayyid Muḥammad 'Alì al-Saqqāf dalam karyanya Al-Salafiyyah al-Wahhābiyyah: Afkāruha al-Asāsiyyah wa Judhüruha al-Asāsiyyah menilai, gerakan wahhabisme ini mewarisi ideologi dan gerakan mujassimah atau mutashabbihah, salah satu aliran teologi dalam Islam yang meyakini Allah SWT memiliki "bentuk" fisik seperti manusia; memiliki wajah, memiliki kedua tangan, bersinggasana di 'Arsy dan tidak di tempat lain. ${ }^{62}$

Berdasarkan eksaminasi teologis dalam karya-karya di atas, hampir tidak ada satupun ulama sunni-mazhabi sejak awal yang menilai Muhammad bin 'Abd al-Wahhāb dan wahhabisme-nya sebagai gerakan pemurnian, pembaharuan, modernisasi atau reformasi keagamaan, termasuk para Ulama Nusantara sendiri. Alih-alih, ulama sunni-mazhabi menilai ajaran dan ideologi wahhabisme sebagai bid'ah, penyimpangan, makar, penerus sekte khawärij, sekte mujassimah dan musyabbihah, dan bughät. Rekam sejarah kritik dan penolakan akademis kaum sunni-mazhabi lintas negara atas Wahhabisme dan berbagai varian gerakan turunannya dan berbagai masalah kemanusiaan yang ditimbulkannya inilah yang menjadi salah satu inspirasi pelaksanaan Muktamar Ulama Dunia yang menghimpun ratusan ulama, sarjana, akademisi dan cendikiawan dari generasi sunni-mazhabi di Chechnya pada Agustus 2016.

Persis pada 25-27 Agustus 2016, sekitar 200 ulama sunni-mazhab $\vec{i}$ lintas mazhab dan negara mengadakan Muktamar Ulama Dunia di Kota Grozny Chechnya bertajuk "Siapakah Ahlu al-Sunnah wa al-Jama'ah: Penjelasan dan Klarifikasi tentang Manhaj Ahlu al-Sunnah wa al-Jama'ah dalam Bidang Akidah, Fiqih dan Tasawwuf serta Penjelasan tentang Akibatnya pada Realitas Dunia Sebab Berpaling dari Manhaj ini" (Man Hum Ahl al-Sunnah wa al-Jamā'ah Bayān wa Tawșīf Manhaj Ahl al-Sunnah wa alJamā'ah I'tiqādan wa Fiqhan wa Sulūkan wa Athar al-Inḥiräf 'anhu 'alā alWàqi').

Dalam Muktamar Chechnya ini, barisan ulama sunni-mazhabī menetapkan sepuluh (10) poin rekomendasi. Salah satu poin penting

59 Muḥammad Jawwād Mughniyyah, Hāàhì Hiya al-Wahhābiyyah, (Qaṭar: Muassasah Dār Kitāb al-Islāmi: Maṭba'ah Satar, 1427H/2007M), h. 130-136.

60 'Āmir al-Kurdì, al- 'Uqdah al-Salafiyah min al-Muqaddasāt al-Islāmiyyah, (Beirūt: Dār al-Kātib al-'Arabi, 1425H/2004M), h. 1-199.

${ }^{61}$ Sayyid Sharif ibnu 'Abd Allāh Sayyid Sharif, Sidqu al-Khabar Fì Khawāriji al-Qarni al-Thānī 'Ashar, (Mișrā: Maṭba' ah Kaumain al-Lazfiyyah, 1428H/2008M), h. 160-168.

${ }^{62}$ Ḥasan 'Ali Al-Saqqāf Al-Ḥusaini al-Shāfi ‘̄i, Al-Salafiyyah al-Wahhābiyyah: Afkāruha al-Asāsiyyah wa Judhūruha al-Asāsiyyah, (Beirūt: Dār al-Mizān, 1430H/2009M), h. 20-22 dan h. 42-54.

Jurnal Tashwirul Afkar Vol. 38, No. 01, Tahun 2020. 
rumusan muktamar menyebut, Ahl al-Sunnah wa al-Jama'ah adalah para ulama dan sarjana lintas negara yang dalam akidah bermanhaj Asy'ariyyahMaturidiyyah, termasuk di dalamnya para ahli hadis (ahl al-hadith) yang berfaham tafwị dalam sifat-sifat Allah Swt atau ulama yang menerima metode ta'wil; dalam fiqih mengikuti salah satu dari empat mazhab (Ḥanafiyyah, Mālikiyyah, Shāfi'iyyah dan Ḥanbaliyyah); dan dalam tasawwuf mengikuti manhaj para sufi agung termasuk Imām al-Junaid al-Baghdādì dan para sufi-sufi agung lainnya. ${ }^{63}$

Poin penting lain yang menjadi kesepakatan dalam Muktamar Chechnya ini adalah konsensus para ulama sunni-mazhabi lintas negara untuk "mengeluarkan" kelompok atau aliran salafi-takfiri (pen: wahhābisme) dari barisan Ahl al-Sunnah wa al-Jamā'ah sebagai penerus salaf al-sāliḥ.64 Muktamar Chechnya ini sekaligus menandai konsolidasi barisan sunnimazhabi lintas negara Islam di tengah himpitan arus deras ideologi salafí (pen: wahhabisme) saat ini yang juga mengklaim diri sebagai penerus Ahl al-Sunnah wa al-Jama'ah. Dalam konteks keindonesiaan, sepuluh (10) rumusan Muktamar Chechnya ini justru makin memperkuat basis epistemis-paradigmatis gagasan Islam Nusantara yang telah jauh-jauh hari dicanangkan Nahdlatul Ulama (NU) sebagai solusi bagi krisis keagamaan dan kemanusiaan dunia dewasa ini, khususnya paska merebaknya arus deras sikap radikalisme, esktrimisme dan aksi terorisme yang berbasis pada ideologi salafi-takfiri di berbagai belahan dunia.

Menimbang dua kutub yang saling bertolakbelakang antara versi para loyalis salafí-wahhābi vis-a-vis barisan sunni-mazhabi lintas mazhab dan negara di atas, muncul pertanyaan, bagaimana diskursus blok orientalis sendiri terkait dengan sosok Muḥammad bin 'Abd al-Wahhāb dan gerakan wahhabisme-nya? Penting dicatat, bahkan sebelum munculnya Wahhabisme, para orientalis barat telah hilir mudik menjelajah dan berpetualang di Jazirah Arab. Begitu juga, menyertai kemunculan Wahhabisme, tercatat banyak orientalis yang aktif melakukan observasi dan bahkan menjadi saksi mata langsung kemunculan gerakan ini.

\section{Diskursus Para Orientalis atas Wahhabisme}

Kehadiran orientalis (scholars, travellers/explorers, state officials) di Jazirah Arab, termasuk di Hijāz (Mekkah, Madinah dan Ṭäif) telah

${ }^{63}$ Shaikh al-Azhar Ahmad al-Tayyib, Man Hum Ahl al-Sunnah wa al-Jamā'ah, Mu'tamar al-Shïshān, (25 Agustus 2016), h. 6-12.

${ }^{64}$ Mu'tamar al-Shīshān, Nașs Bayān Mu'tamar Man Hum Ahl al-Sunnah wa al-Jamā'ah Bayān wa Tawșíf Manhaj Ahl al-Sunnah wa al-Jamā'ah I'tiqādan wa Fiqhan wa Sulūkan, (Grozny-Chechnya, 25-27 Agustus 2016), h. 1-4. 
berlangsung ratusan tahun. Rekam jejak para orientalis awal berdasarkan sumber-sumber tertulis yang dapat penulis sebutkan jauh "sebelum" kemunculan Muhammad bin "Abd al-Wahhāb dan gerakan Wahhabisme, antara lain: Ludovico de Bartema atau Ludivico di Varthema (1503M); ${ }^{65}$ Vincent Le Blanc (1568M);66 Johann Wild (1607M); Joseph Pitts (1680M);67 dan beberapa yang lain. Mengingat periode ini kurang begitu relevan, penulis hanya mencermati karya-karya orientalis yang semasa atau berdekatan secara periodik atau yang berdekatan dengan kemunculan dan penyebarluasan Wahhabisme.

Para orientalis yang menjelajah atau bertugas di Jazirah Arab dan secara periodik bersamaan dengan kemunculan dan ekspansi Wahhabisme menyajikan penilaian yang sangat bertolak belakang dengan kesimpulan akhir para "kritikus" dari barisan sunni-mazhabi lintas mazhab dan lintas dunia Islam masa itu. ${ }^{68}$ Penilaian sangat berbeda ini terekam jelas dalam karya-karya para orientalis, antara lain: Domingo Badia Leblich alias "Ali Bey" (1767-1818M) dan John Lewis Burckhardt alias "Syaikh Hajj Ibrahim" (1784-1817M). ${ }^{69}$ Sir Harford Jones Brydges (1764-1847M), Lewis Pelly (1825-1892M), William Gifford Palgrave (1826-1888M), Augustus Ralli (1829-1902M), Charles Mentagu Doughty (1843-1926M), Ignaz Goldziher (1850-1921M), Snouck Hurgronje (1857-1936M), Henri Laoust (19051983M).

Orientalis Domingo Badia "Ali Bey" Leblich (1767-1818M) yang berpetualang selama 2 tahun di Mekkah, Jeddah, Madinah dan Yerusalem antara tahun 1806-1807 Masehi dan menggunakan nama samaran muslim "Hajji Ali Bey El-Abbasi" dalam karyanya Travels of Ali Beymencatat, "Berkat dukungan penuh Ibnu Sa'ud, gerakan reformasi keagamaan Muhammad bin 'Abd al-Wahhāb diterima dengan baik oleh hampir seluruh suku Baduwi atas perintah Ibnu Sa'ud. Hal ini sekaligus menjadi dalih bagi keduanya

65 Ludovico di Varthema, The Travels of Ludovico Di Varthema in Egypt, Syria, Arabia Deserta and Arabia Felix in Persia, India and Ethiopia 1503-1508, translated from Italian by John Winter Jones, (London: Printed for Hakluyt Society, 1863), 1-492. John Wallen, "Burton in Makkah and Medina: Sufi Aspirant or Imperialist Spy?", Journal of University of Nizwa, Issue: 2.3, (2014), h. 2 dan 34.

66 Vincent Le Blanc, The World Surveyed, translated from French into English by F.B. Gent, (London: John Starkey at the Miter, 1660M), h. 1-454.

${ }^{67}$ Augustus Ralli, Christians at Mecca, (London: William Heinemann, 1909), h. vii.

68 Khawājah Muḥammad Ḥasan Jān al-Ḥanafí, Al-Usūul al-Arba'ah Fì Tardìd alWahhābiyah, taḥqiq Hakīm Muḥammad Mi'rāj al-Dīn Aḥmad, (Istānbūl-Turkī: Darussefaka, Isik Kitabevi, 1431H/2010M), 1-128. Penulis secara detil mengupas topik ini dalam bab IV. ${ }^{69}$ Giovanni Bonacina, The Wahhabis Seen through European Eyes, h. 108-168. 
untuk menyerang suku-suku lainnya, sehingga pilihan yang tersisa hanya menjadi pengikut Wahhabi atau terbunuh oleh pedang sang reformis" ${ }^{70}$

Domingo Badia Leiblich menambahkan kesaksian, "sang reformis Muhammad bin 'Abd al-Wahhāb tidak bertujuan untuk kemuliaan pribadi atau meraih simpati, sebab dia sekedar pimpinan sekte keagamaan yang tidak haus simpati dan jabatan. Sepeninggal Muhammad bin 'Abd alWahhāb, sang putra melanjutkan gerakan reformasinya". ${ }^{71}$ Selain menyebut Muhammad bin 'Abd al-Wahhāb sebagai tokoh reformasi keagamaan, Dominggo Leiblich dalam catatan Augustus Ralli juga menyebut pengikut Wahhabi sebagai "muslim puritan". ${ }^{72}$

Diskursus senada juga terekam dalam karya orientalis lain, John Lewis Burckhardt dalam Notes on Bedouins and Wahhabys. Burckhardt merupakan alumni Universitas Cambridge London dan selama 2 tahun lebih berpetualang di Mesir, Mekkah, Madinah antara tahun 1814-1815 Masehi. Selama bertualang, Burckhardt menggunakan nama samaran muslim "Shaikh Hajj Ibrahim".73 Dalam karyanya ini, Burckhardt menulis, "setelah beralih menjadi pengikut ajaran Wahhabi (sejak 15 tahun lalu), penduduk Aenezeh (pen: 'Uyainah) mulai secara aktif mengerjakan shalat. Sebab, pemimpin Wahhabi sangat rigid menghukum siapa pun yang mengabaikan shalat. Burckhardt menambahkan, beragaman opini dan penilaian muncul sebagai respon atas ajaran dan doktrin Wahhābì. Bahkan, selama berpetualang di Suriah, aku sendiri tidak menemukan satupun ahli agama yang bisa menjelaskan kebenaran tentang ajaran mereka (Wahhabi). Sebab itu, berdasarkan penelusuranku, aku pribadi lebih suka menyebut gerakan Wahhabi mirip dengan gerakan Protestanisme atau Puritanisme Islam".74

John Lewis Burckhardt (Shaikh Hajj Ibrahim) menambahkan, "gerakan Wahhabi hanya mengakui al-Qur'an sebagai satu-satunya kebenaran; prinsip dasar mereka "tidak ada sumber kebenaran selain dari al-Qur'an". Sebab itu, kaum Wahhabi hampir menolak seluruh Hedayth (pen: Hadith) atau "tradisi" ijtihad warisan para ahli hukum Islam (pen: fuqaha'), dan (menafsirkan) al-Quran versi mereka. Kaum Wahhabi mengakui kemuliaan Nabi Muhammad SAW hanya ketika masih hidup bersama para sahabatnya. Sebaliknya, sepeninggal-Nya, kaum Wahhabi melarang umat Islam untuk

70 Domingo Badia Y Leblich, Travels of Ali Bey, (London: Longman, Hurst, Fees, Orme, and Brown, 1816M), Volume II, h. 152.

${ }^{71}$ Domingo Badia Y Leblich, Travels of Ali Bey, Vol II, h. 157.

${ }^{72}$ Augustus Ralli, Christians at Mecca, h. 55.

${ }^{73}$ Augustus Ralli, Christians at Mecca, h. 74.

${ }^{74}$ John Lewis Burckhardt, Notes on the Bedouins and Wahabys, (London: Henry Colburn and Ricard Bentley, 1831M), Vol I, h. 101. 
berziarah ke Makam-Nya di Madinah, seraya mamaksa umat Islam hanya berziarah ke Ka'bah, dan hanya membolehkan menyembelih kurban di padang Arafah, sebagai ibadah tertinggi dalam ritual Haji di Mekkah. Seluruh pengikut Wahhabi berpakaian seadanya, mengharamkan rokok sebab mereka menganggap rokok menyebabkan kebodohan dan beracun". ${ }^{75}$

Selain itu, John Lewis Burckhardt menulis, kaum Wahhabi melarang seluruh pengikutnya bermain musik, bernyayi, menari dan setiap bentuk permainan, dan menjalani hidup di bawah kontrol penuh setiap pemimpin wilayahnya. Kaum Wahhabi melarang perkawinan antara pengikutnya dan kaum musrikin (pen: umat Islam) di luar sektenya. Kaum Wahhabi di bawah komando Ibnu Sa'ud selalu mengkampanyekan agamanya dengan pedang (pen: perang). Setiap kali Ibnu Sa'ud hendak menginvasi satu wilayah tertentu, dia mengirim surat peringatan tiga kali, berisi seruan untuk tunduk dan patuh dengan ajaran Wahhabi. Setelah peringatan ketiga, tidak ada lagi ampunan bagi pihak yang menolak. Ibnu Sa'ud langsung mengirim pasukan dan memerintahkan pasukan Wahhabi untuk menjarah harta benda dan mengeksekusi sesuka hati, seperti saat masjid 'Ali berhasil dikuasai, pasukan Wahhabi mengeksekusi penduduknya".76

John Lewis Burckhardt memberi catatan tambahan, tiap kali pasukan Wahhabi berhasil menguasai satu daerah tertentu, saat itu pula menjadi sepi senyap. Di Najd dan Hijāz, jalan-jalan sepi. Siapapun yang bertahan "dipaksa" mengikuti ajaran Wahhabi, kecuali orang Yahudi dan Kristen yang dinilai masih menjalankan ajaran-ajaran para leluhurnya, atau boleh menetap selagi membayar pajak. Sebab, salah satu doktrin dasar kaum Wahhabi adalah membayar upeti (pajak) kepada sang pemimpin. ${ }^{77}$

Ironisnya, meski banyak mengungkap fakta kekerasan gerakan Wahhabi, tetapi John Lewis Burckhardt memberi penilaian akhir bahwa gerakan keagamaan yang dimotori Muḥammad bin 'Abd al-Wahhāb sebagai gerakan "reformasi" keagamaan dari berbagai penyimpangan akidah umat Islam saat itu, sekaligus sebagai gerakan pemurnian akidah (puritan) yang selama ini cenderung cemar dengan berbagai praktek-praktek yang menyimpang dari ajaran sebenarnya. ${ }^{78}$

\footnotetext{
${ }^{75}$ John Lewis Burckhardt, Notes on the Bedouins and Wahabys, Vol I, h. 101-102.

${ }^{76}$ John Lewis Burckhardt, Notes on the Bedouins and Wahabys, Vol 1, h. 103.

77 John Lewis Burckhardt, Notes on the Bedouins and Wahabys, Vol I, h. 104.

${ }^{78}$ John Lewis Burckhardt, Notes on the Bedouins and Wahabys, Vol II, h. 99.
} 
Meski dengan detilitas dan ekspos fakta yang berbeda dengan John Lewis Burckhardt, Sir Harford Jones Brydges (1764-1847M), ${ }^{79}$ salah satu atase Inggris yang telah menjelajah selama 25 tahun di Bashra, Shiraz, Baghdad, Iran dan Kuwait, menyetujui penilaian Burckhardt bahwa gerakan Muhammad bin 'Abd al-Wahhāb dan model pemerintahan (tata kelola) yang dirancang para pengikut Wahhabi mencerminkan corak sikap puritanisme dan reformasi keagamaan. Jones Brydges juga mencatat, upaya Muhammad bin 'Abd al-Wahhāb dan Ibnu Sa'ūd merupakan upaya reformasi keagamaan semata atas berbagai penyimpangan dan penyalahgunaan para ahli agama saat itu, termasuk demi mengembalikan umat Islam pada akidah yang benar. ${ }^{80}$

Orientalis Inggris lain adalah James Silk Buckingham (1786-1855M) juga memberikan penilaian yang sama. Menurut Buckingham, seperti dikutip Giovanni Bonacinna, meskipun banyak memicu peperangan dan menimbulkan kekacauan di Jazirah Arab, gerakan Wahhabis merupakan gerakan pembaharuan dan reformasi keagamaan dengan karakteristik ideologi puritan..$^{81}$

Orientalis lain yang menilai gerakan Wahhabisme sebagai gerakan reformasi adalah William Gifford Palgrave (1826-1888M). Gifford Palgrave mencatat, "Saat terjadi reformasi total di Riyad tahun 1856, seperti penjelasanku dalam bab sebelumnya, para pengkhotbah (Wahhabi) berkeliling di kota Hofuf (ibu kota provinsi Aḥsà') sembari mengobarkan seruan peperangan di seantero wilayah. Sangat mungkin akibat korban perang tersebut mempercepat penyebaran penyakit kolera di wilayah ini". ${ }^{82}$

Agak berbeda dengan kutipan di atas, menurut Giovanni Bonacina, William Palgrave tidak hanya menilai ajaran Muhammad bin 'Abd al-Wahhāb dan gerakan Wahhabismenya mirip dengan gerakan reformasi kaum

${ }^{79}$ Giovanni Bonacina, The Wahhabis Seen through European Eyes (1772-1830): Deists and Putitan of Islam, (Leiden and Boston: Brill, Volume 1, 2015), h. 8 dan 87.

80 Sir Harford Jones Brydges, An Account of the Transactions of the Majesty's Mission to the Courth of Persia in the Years 1807-1811 with Notes on the Wahhabiya, (London: James Bohn, King William Street, West Strand, Volume I, 1834M), h. 107-108.

81 Giovanni Bonacina, The Wahhabis Seen through European Eyes, h. 184.

82 William Gifford Palgrave, A Personnal Narrative of A Year's Journey Through Central and Eastern Arabia 1862-1863, (London and New York: Macmillan and Company, Sixth Edition, $1873 \mathrm{M}$ ), 359. Tentang wabah kolera di Hijāz ini, penulis menemukan versi tahun berbeda. Menurut Michael Cristhoper Low, peristiwa penyebaran wabah kolera di Hijaz ini terjadi pada tahun 1865 Masehi, dan menewaskan sekitar 15.000 ribu peziarah dan penduduk di Hijāz. Michael Cristhoper Low, "Empire of Hajj: Pilgrims, Plagus, and PanIslam under British Surveillance 1865-1926", Thesis, George State University, (July, 2007), h. 5-6. 
Protestanisme Kristen, namun lebih jauh lagi, gerakan Wahhabi ini bisa dikategorikan lebih mirip dengan "gerakan Supralapsarianism", atau dalam analogi dan diksi Giovanni Bonacina mirip dengan gerakan reformasi kaum Calvinis. ${ }^{83}$

Charles Mentagu Doughty (1843-1926M) meski dalam karyanya Travel in Arabia Deserta banyak mengungkap tabiat kaum Wahhabi yang suka berperang, fakta ini tidak merubah penilaian Daughty seperti para orientalis sebelumnya, bahwa gerakan keagamaan yang dimotori Muhammad bin 'Abd al-Wahhāb dan Ibnu Sa'ūd adalah gerakan reformasi berdasarkan doktrin dan ideologi puritanistik. Sebaliknya, Charles Daughty menilai, masyarakat Arab saat itu yang masih suka berziarah ke tempattempat wali dan orang shalih dan menilainya sebagai bentuk "kuno" (the unreformed). ${ }^{84}$

Snouck Hurgronje (1857-1936M) dalam The Revolt of Arabia menyajikan kesimpulan akhir yang sama. Hurgronje mencatat, gerakan Wahhabisme adalah gerakan yang lahir dari semangat puritanisme dan reformasi keagamaan untuk mengoreksi praktek yang mereka anggap justru menghinakan Islam, termasuk ketika mengobarkan "perang suci" (the holy war) melawan dominasi Negara Turki 'Uthmani. Ironinya, Snouck Hurgronje melihat kesuksesan sekte Wahhabi menguasai hampir seluruh Jazirah Arab ini sama dengan kesuksesan dakwah Nabi Muhammad SAW 12 abad sebelumnya. ${ }^{85}$ Snouck Hurgronje dalam karya lainnya Mohammadenism menegaskan, gerakan Mụammad bin 'Abd al-Wahhāb dan Wahhabisme-nya sebagai gerakan reformasi keagamaan. ${ }^{86}$

David George Hogarth (1862-1927M) dalam karyanya The Penetration of Arabia juga menilai gerakan Wahhabisme sebagai gerakan kebangkitan (revival) sekaligus reformasi keagamaan. ${ }^{87}$ Memasuki abad 19, penulis

83 Ulasan tentang analogy Calvinisme Protestan dan Radikalisme Islam, lihat Richard Mansbach, "Calvinism as a Precedent for Islamic Radicalism", The Brown Journal of World Affairs, Vol. 12, No. 2 (Winter/Spring 2006), h. 103-15.

84 Charles Montagu Doughty, Travels in Arabia Deserta, Volume II, (London and Boston: Philip Lee Warner, Publisher to the Medici Society, LTD., an Jonatahan Cape, Vol I \& II, 1921M), h. 538.

85 Christian Snouck Hurgronje, The Revolt in Arabia, with a Foreword by Richard J.H. Gotheil, (New York and London: The Knickerbocker Press, 1917M), h. 20.

${ }^{86}$ Christian Snouck Hurgronje, Mohammadenism: Lectures on Its Origin, Its Religious and Political Growth, and Its Present State, (New York: G.P. Putnam's Son, 1916M), h. 82 dan 141.

87 David George Hogarth, The Penetration of Arabia: A Record of the Development of Western Knowledge Concerning the Arabian Peninsula, )New York: Frederick A. Stokes Company, 1904). h. 76.

Jurnal Tashwirul Afkar Vol. 38, No. 01, Tahun 2020. 
menemukan penilaian beberapa barisan "neo-orientalis" masih seirama dengan generasi orientalis sebelumnya, bahwa gerakan Wahhabi merupakan gerakan reformisme, modernisme atau gerakan revivalisme keagamaan bercorak puritanistik, antara lain: David Samuel Margoliouth (1858-1940M); ${ }^{88}$ Samuel Zwemer (1867-1952M); ${ }^{89}$ Kathryn Tidrick (18761958M); ${ }^{90}$ Max Trautz (1880-1960M); ${ }^{91}$ Harry Saint John Philby (18851960M); ${ }^{92}$ TE Lawrence (1888-1935M); ${ }^{93}$ Halford Hoskins (1891-1967M); ${ }^{94}$ WF Smalley (1897-1983M), ${ }^{95}$ dan beberapa lainnya.

\section{Dominasi Diskursus Orientalis/Neo-Orientalis dan Loyalis}

Memasuki abad 20, penilaian bahwa gerakan Muhammad bin 'Abd alWahhāb dan Wahhabisme adalah gerakan reformasi keagamaan ini sama sekali belum bergeser dan justru makin mendominasi dunia Islam, khususnya dalam studi-studi Islam di Barat. Fakta ini terekam misalnya dalam tulisan neo-orientalis Henri Laoust (1905-1983M) berjudul "Ibn 'Abd al-Wahhab" yang terbit dalam The Encyclopaedia of Islam. ${ }^{96}$ Diskursus ini bahkan mendominasi dan menjadi "kuasa" pengetahuan yang terus direplikasi sebagian sarjana dan neo-orientalis dan sarjana barat generasi berikutnya semisal George Snavlye Rentz (1912-1963M); ${ }^{97}$ Bernard Lewis (1916-2018M); ${ }^{98}$ Bayly Winder (1920-1988M); ${ }^{99}$ Zahra Freeth (1925-

${ }^{88}$ David Samuel Margoliouth, "Wahhabiya", dalam HAR Gibb dan JK Kramers (Eds), Shorter Encyclopaedia of Islam, (Leiden: EJ Brill, 1953), h. 618.

${ }^{89}$ Samuel Zwemer, "Islam in Arabia Deserta", Muslim World, 33 (1943), h. 157-164.

${ }^{90}$ Kathryn Tidrick, Heart-Beguiling Araby, (New York: Cambridge University Press, 1981), h. 2, 65, 66, 124, 127, 138, 139, 142.

${ }^{91}$ M. Trautz, "G.A. Wallin and the Pnenetration of Arabia", (The Geographical Journal, 76 (August 1930), h. 248-252.

${ }^{92}$ Harry St. John Philby, Arabia of the Wahhabis, (New York: Arno Press, 1973).

93 TE Lawrence, Seven Pillars of Wisdom: A Triumph, Cet. Ke-1, (Delhi: Oxford University Press and Bombay Calcutta Madras, 1940), h. 39.

${ }^{94}$ Halford Lancaster Hoskins, "Background of the British Position in Arabia", Middle East Journal, Volume 1 (1947), h. 137-147, 141.

95 William F. Smalley, "The Wahhabis and Ibn Saud", Muslim World, 22 (1932M), h. 227-246.

${ }^{96}$ Henri Laoust, "Ibn 'Abd al-Wahhab", dalam B. Lewis, VL. Menage, CH. Pellat, Joseph Schacht (Eds), The Encyclopaedia of Islam: New Edition, (Leiden: E.J Brill and London: Luzac \& Co., 1986), Volume III, H-IRAM, h. 678.

${ }^{97}$ George Snavlye Rentz, "Muhammad Ibn 'Abd al-Wahhab and the Beginnings of the Unitarian Empire in Arabia", (Dissertation of University of California at Barkeley, 1948), h. 4, 19, 21, 24, 40, 41, 28, 29, 35, 50, 51, 52, 173.

98 Bernard Lewis, The Arab in History, (London: Hutshinson House \& Anchor Press, Ltd., Second Edition, 1954), h. 160-163.

99 Ricard Bayly Winder, Saudi Arabia in the Nineteenth Century, (New York: St. Martin's Press, 1965), h. 14, 38. 
2015M) dan HVF Winstone (1926-2010M);100 Kamal Salibi (19292011M); ${ }^{101}$ Robin Bidwell (1929-1994M). ${ }^{102}$

Pada era lebih kontemporer misalnya, Sohail Humayun Hashmi (1950sekarang) menulis biografi tentang Muhammad bin 'Abd al-Wahhāb sebagai tokoh reformasi konservatif sekaligus inspirator gerakan reformasi di dunia Islam, dan bahkan menyimpulkan bahwa ajaran Muhammad bin 'Abd alWahhāb bersumber dari tradisi keilmuan Ahmad bin Hanbal dan Ibnu Taimiyyah, ${ }^{103}$ sekaligus menahbiskan sebagai inspirasi gerakan-gerakan pembaharuan di dunia Islam lainnya termasuk gerakan pembaharuan Shah Wali Allah al-Dihlawi (1703-1762) d India. ${ }^{104}$

Diskursus yang sama masih penulis temukan dalam karya-karya sarjana barat kontemporer termasuk Natana J Delong-Bas (1950-sekarang) juga menyajikan penilaian yang sama. ${ }^{105}$ Penulis mencukupkan dengan mengutip kesimpulan akhir Natana J Delong-Bas dalam buku Wahhabi Islam: From Revival and Reform to Global Jihad tentang penilaiannya bahwa Muhammad bin 'Abd al-Wahhāb merupakan tokoh gerakan reformasi Islam, dan jauh berbeda dari gerakan fundamentalisme dan terorisme, sebagai berikut:

"Penekanan Ibn Abd Al-Wahhab tentang pentingnya nilai Islam dan maksud di balik kata dan tindakan, sebagai lawan dari kepedulian terhadap kesempurnaan ritual, telah membuka pintu untuk melakukan reformasi hukum Islam, meningkatkan status perempuan dan kaum minoritas, serta penyebaran Islam damai dan misi Islam sebenarnya di era kontemporer. Sebagai aktivis abad kedelapan belas, Ibnu Abd AlWahhab mewakili beberapa kecenderungan intelektual yang paling penting pada masa itu, terutama metodologi baru dalam bidang kritik hadits yang lebih menekankan isi dibanding bentuk. (..) Ibn Abd Al-Wahhab tidak menciptakan metode kritik hadis sendiri. Akan tetapim ia, seperti laiknya tokoh sezaman lainnya, seperti Shah wali Allah, ia mempelajarinya dari gurunya di Mekah dan Madinah". ${ }^{106}$

100 Zahra Freeth dan HVF Winstone, Explorers of Arabia, (London: George Allen and Unwin, 1978), h. 101.

${ }^{101}$ Kamal Suleiman Salibi, A History of Arabia, (New York: Caravan Books, 1980), h. 160, 175, 191, 193.

102 Robin Leonard Bidwell, Travellers in Arabia, (New York: The Hamlyn Publishing Group Limited, 1976), h. 27, 29, 31, 76, 208, 144, 145, 148.

${ }^{103}$ Sohail H Hashmi, "'Abd al-Wahhab, Muhammad Ibn (1703-1792)”, dalam Richard

C Martin (Eds.), Encyclopedia of Islam and the Muslim World, (New York: Thomson Gale, Volume 1, 2004), h. 6.

${ }^{104}$ Sohail Humayun Hashmi, "Wahhabiyya", h. 728.

105 Natana J. Delong-Bas, Wahhabi Islam: From Revival and Reform to Global Jihad, (London: Oxford University Press, 2004), h. 17.

106 Natana J Delong-Bas, Wahhabi Islam, h. 281-282.

Jurnal Tashwirul Afkar Vol. 38, No. 01, Tahun 2020. 
Sikap pembelaan Delong-Bas atas Wahhabisme dan bias penilaiannya dalam bidang studi Islam juga nampak dalam beberapa statemen lainnya, bahwa Ayman al-Zawahiri, salah satu pemimpin al-Qaeda, merupakan salah satu "guru sufi penting" (a major sufi syeikh); ${ }^{107}$ doktrin dan ajaran Wahhabisme sangat menghargai tradisi, ${ }^{108}$ spiritualitas, ${ }^{109}$ penuh cinta damai dan sangat sejalan dengan gerakan feminisme; ${ }^{110}$ serta kesimpulan Delong-Bas bahwa Muhammad bin 'Abd al-Wahhāb merupakan penerus mata rantai dan cita-cita Ibnu Taimiyyah dan Ahmad bin Hanbal,111 tanpa melakukan uji perbandingan atau verifikasi ilmiah sejauhmana kesamaan dan perbedaan gagasan antara tokoh-tokoh tersebut.

Berdasarkan paparan ketiga diskursus di atas, muncul pertanyaan, apa parameter para orientalis atau neo-orientalis dalam menilai Muhammad bin 'Abd al-Wahhāb dan Wahhabisme-nya layak mendapat label penyematan dan citra sebagai tokoh modernisasi keagamaan, pembaharuan dan bahkan reformasi keagamaan? Mengapa para orientalis sebagai outsiders "seolah" mengabaikan kritik dan penolakan para sarjana sunni-mazhabi lintas mazhab dan negara masa itu? Adakah agenda "kuasa-politik" para orientalis masa itu dalam mencitrakan Muhammad bin 'Abd al-Wahhāb dan Wahhabisme-nya dengan berbagai label prestisius di atas? Apakah kesamaan penilaian ini terjadi secara kebetulan (coincident) atau justru menggambarkan relasi kuasa-pengetahuan antara kuasa-orientalis dengan kuasa-wahabis masa itu?

Melalui pemetaan di atas, penulis menggarisbawahi beberapa poin temuan penting sebagai berikut. Pertama, konstruks diskursif tentang Wahhabisme yang tersaji baik dalam sumber-sumber "orientalis" maupun sumber-sumber "loyalis" sangat identik dan memiliki kesamaan; memposisikan Muhammad bin 'Abd al-Wahhāb dan Wahhabisme sebagai gerakan pemurnian (puritanism), pembaharuan (tajdid), modernisasi dan reformasi keagamaan, sebagaimana penulis uraikan dalam diskripsi poin sebelumnya.

Kedua, setelah menyandingkan periodisasi petualangan para orientalis di Jazirah Arab dengan periode penyebarluasan wahhabisme di Jazirah Arab, penulis menggarisbawahi, periode penjelajahan orientalis dapat dimaknai lebih "mendahului" atau minimal "menyertai" periode kemunculan

${ }^{107}$ Natana J. Delong-Bas, Wahhabi Islam, h. 274.

${ }^{108}$ Natana J. Delong-Bas, Wahhabi Islam, h. 48, 124, 161, 190, 228-257.

${ }^{109}$ Natana J. Delong-Bas, Wahhabi Islam, h. 35, 75-76.

${ }^{110}$ Natana J. Delong-Bas, Wahhabi Islam, h. 183, 185.

111 Natana J. Delong-Bas, Wahhabi Islam, h. 35, 243-244, 287-289. 
Wahhabisme itu sendiri. Jika konsisten dengan poin kedua ini, citra dan label yang belakangan diadopsi blok-loyalis yang menahbiskan Muhammad bin 'Abd al-Wahhāb dan Wahhabisme-nya sebagai tokoh gerakan puritan, modernisasi dan reformasi juga bisa "dimaknai" berasal dari epistempengetahuan blok-orientalis yang pada masa ini tentu lebih dodiminasi agenda "kolonial" dengan basis pertimbangan-pertimbangan politik-kuasa, sebagaimana disinggung Edward W. Said di atas.

Ketiga, setelah menelusuri diskursus dan narasi dalam sumbersumber orientalis di atas, penulis tidak menemukan satupun parameter atau tolak ukur rasional akademis yang dijadikan "pedoman" dalam penilian akhir mereka, baik pada level epistemis maupun paradigmatis. Jika membaca karya-karya orientalis peridoe ini, kita akan banyak dihadapkan pada "kontradiksi" sikap. Misalnya, para orientalis cukup detil mendiskripsikan berbagai bentuk "kekerasan" yang dilakukan laskar Wahhabi selama ekspansi dan okupasinya terhadap warga sipil sehingga menimbulkan korban jiwa dalam jumlah besar, termasuk kerusakan infrasturktur sosial politik mas itu yang tak terhitung, namun dalam kesimpulan akhirnya, tetap saja para orientalis/neo-orientalis tetap saja menilai Muhammad bin 'Abd al-Wahhab sebagai tokoh modernisasi dan reformasi keagamaan. Fenemone ini menunjukkan, para orientalis periode itu tidak memiliki parameter yang ilmiah dan kredible, dan lebih didorong pada agenda kuasa.

Keempat, penyematan orientalis kepada Muhammad bin 'Abd alWahhāb sebagai tokoh puritanisme (pemurnian) akidah ini juga bias dan sangat politis. Mengapa? Jika puritanisme dimaknai sebagai upaya "pemurnian", pertanyannya, apa yang dimurnikan? Apa yang tercemar sehingga harus dimurnikan? Apakah tuntutan pemurnian itu juga mewakili tuntutan mayoritas umat Islam saat itu? Lagi-lagi, penulis tidak menemukan satupun orientalis masa itu yang mampu melakukan eksaminasi teologis dan ideologis secara mendalam dan berimbang, sehingga jika menyebut kata "pemurnian" memiliki basis argumentasi yang ilmiah. Padahal langkah paling sederhana bisa dilakukan para orientalis, misalnya dengan melihat respon masyarakat Islam masa itu, membandingkan dan melacak akar-akar pemahaman teologis ke dalam tradisi keislaman klasik, atau minimal merujuk pada penilaian para sarjana, akademisi sunni-mazhabi dan menyandingkannya secara berimbang, sehingga tidak memunculkan kesimpulan yang bias, politis dan berat sebelah.

Kelima, lebih ironis ketika penulis membaca kutipan-kutipan dalam karya orientalis dan menemukan fakta, para orientalis masa itu justru 
menilai ajaran, teologi, tatanan dan praktek keagamaan masyarakat Arab masa itu (pen: amaliah kaum sunni-mazhabi) sebagai tatanan keagamaan kuno, unreformed, dipenuhi praktek kultus, dipenuhi bid'ah dan penyimpangan, tidak sesuai dengan ajaran murni, dan sekian banyak label peyoratif lainnya? Lagi-lagi, penilaian sepihak dan peyoratif para orientalis atas praketk keagamaan kaum sunni-mazhabi ini tidak didukung dengan eksaminasi teologis secara ilmiah akademis. Padahal, jika mencermati kritik dan penolakan kaum sunni-mazhabi dalam berbagai karya di atas justru menunjukkan kualitas keilmuan, kecendikiawnana dan kedalaman tradisi keilmuan sunnī-mazhabīlintas mazhab dan negara.

Konstruks diskursif kritis atas Wahhabisme yang tersaji dalam sumber-sumber sunni-mazhabī (Hanafí, Māliki, Shäfi ${ }^{\top} \bar{i}$ dan Hanbali) jauh lebih kritis, argumentatif, filosofis dan rasional berdasarkan parameterparameter ilmiah yang kredibel dan legitimate. Misalnya, kaum sunnimazhabi lintas mazhab melacak dan menelusuri basis penisbatan ajaran Muhammad bin 'Abd al-Wahhāb hingga ke genarasi salaf al-șālih (sahabat, tabi'in dan tabi' al-tabi'in) baik dalam ranah 'aqìdah, fiqh dan siyāsah. Berdasarkan uji tiga ranah tersebut, sumber-sumber sunni-mazhabi menetapkan kesimpulan, Wahhabisme Muhammad bin 'Abd al-Wahhāb dan berbagai variannya adalah gerakan penyimpangan (inhiräf), subversif (makar) dan secara teologis bertolakbelakang dengan sanad dan manhaj salaf al-șālị̆ yang menjadi ijmā' (konsensus) mayoritas sarjana sunnímazhabi dari berbagai dunia, termasuk Irak, Iran, Sham (Suriah, Lebanon, Palestina, dan Yordania), Mesir, India, Malaysia, Thailand, Brunei, dan bahkan Indonesia sendiri. Akan tetapi, para orientalis justru menegaskan sebaliknya, bahwa tradisi keilmuan Muḥammad bin 'Abd al-Wahhāb bersumber dari manhaj Ahmad bin Ḥanbal, sebuah penisbatan yang sangat bias dan berat sebelah.

Ketujuh, diskursus atas Wahhabisme yang bersumber dari pengetahuan orientalis ini sekaligus merepresentasikan dominasi kuasakolonial di Jazirah Arab masa itu. Diskursus ini selanjutnya diadopsi kaum salafí-wahhābi (ideolog, aktifis dan simpatisan), termasuk sebagian besar sarjana barat hingga kini. Secara politis, strategi ini merupakan mekanisme mempertahankan status-quo demi kesinambungan otoritas "episteme kolonial".

Konstruks diskursif ini "dilestarikan" melalui berbagai medium, termasuk literatur, media, buku, film, dan lain-lain, termasuk melalui kontektualisasi dan pemutakhiran diksi, istilah, terminologi, seperti metamorfosis terma wahhābiyyah atau al-muwaḥhidūn (barisan ahli tauhid) 
menjadi penerus al-salaf al-șàliḥ, al-firqah al-nājiyah (kelompok yang selamat), al-sawad al-a'zam (barisan mayoritas yang benar), al-tā'ifah almansürah (kelompok pemenang), dan lebih ironis menahbiskan diri sebagai penerus manhaj ahl al-sunnah wa al-jamā'ah paling abasah, meskipun dengan cara-cara misinformasi dan disinformasi berbagai karya kaum sunnimazhabỉ lintas generasi demi agenda politik mereka.

Kedelapan, menimbang label dan citra Wahhabisme lahir dari agenda kolonial dan episteme-eurosentrisme, maka ideologi dan gerakan Wahhabisme menurut penulis "muncul" bukan dari "rahim" kesadaran sosial politik keagamaan umat Islam saat itu, dan sama sekali "tidak mewakili" agenda atau tuntutan perubahan sosial keagamaan masyarakat Arab masa itu. Alih-alih, gerakan Wahhabisme mengemuka sebagai pilihan strategis kebijakan ekspansionisme kolonialisme Barat di Jazirah Arab. Mengapa demikian?

Pasalnya, baik secara sosial, politik, ekonomi dan teologi, penulis tidak menemukan rekam jejak ketidakadilan, atau bentuk-bentuk penindasan dan diskriminasi, atau pola-pola otoritarianisme yang dipaksakan penguasa muslim masa itu kepada warga Najd atau Hijaz, sehingga menjadikannya laik menjadi raison d'être bagi munculnya satu gerakan keagaaman tertentu dengan agenda purifikasi, modernisasi, reformasi keagamaan dan perubahan politik secara menyeluruh. Kecuali, misalnya ada kebijakan pemerintah muslim masa itu semisal Amir Mekkah atau Kesultanan Turki Uthmani yang bersifat otoriter, represif, penuh dengan ketidakadilan dan mendapat legitimasi-teologis para elit agama khususnya kaum sunnimazhabī masa itu, tentu situasi dan kondisi ini sangat memungkinkan bagi lahirnya gerakan perlawanan dan tuntutan reformasi secara menyeluruh.

Kesembilan, kemenangan politik Wahhabisme sehingga berhasil mengokupasi Hijäz dan Jazirah Arab dan keluar sebagai "pemenang" juga tak terlepas dari episteme-episteme dan momen-momen penting kolonial. ${ }^{112}$ Kuasa diskursif kolonial masa itu turut secara aktif membentuk realitasrealitas diskursif tentang Wahhabisme, sembari menegasikan dan mendiskriminasikan "realitas-realitas" diskursif kesarjanaan muslim lainnya, khususnya diskursus sunni-mazhabi . Relasi-relasi ini makin

112 Imran N. Hosein, The Caliphate, The Hejaz and The Saudi Wahhabi Nation State, (New York: Masjid Dar al-Quran, 1996), h. 14-27.

Jurnal Tashwirul Afkar Vol. 38, No. 01, Tahun 2020. 
dikukuhan melalui momentum-momentum kolonial, termasuk melalui Perjanjian Darin pada 26 Desember 1915M antara kerajaan Inggris-Saudi. ${ }^{113}$

\section{Kesimpulan}

Penting penulis tegaskan di akhir, paper ini melakukan eksplorasi khusus dalam bidang studi-studi keislamam (islamic studies), sehingga menimbang dominasi dan hegemoni "residu" diskursus orientalis dan loyalis yang menjangkiti banyak sejarawan, sarjana, akademisi dan peneliti keislaman di kampus maupun non-kampus termasuk di Indonesia dan sistem pendidikan nasional kita, perlu untuk mulai kembali mengangkat dan memperbanyak seri-seri kajian islam berdasarkan sumber-sumber induk keislaman awal model Islam Nusantara dengan basis pesantren sebagai khazanah paling otentik sekaligus warisan berkesinambungan barisan ulama, sarjana dan cendekiawan sunni-mazhabi dunia, baik pada bidang

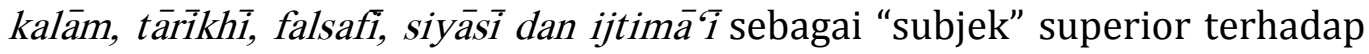
studi-studi islam yang dikembangkan di Barat, dan senantiasa melakukan verifikasi dan uji ilmiah, membandingkan berbagai sumber termasuk ketika mengupas sejarah Wahhabisme sendiri, seperti tradisi para sarjana dan sejarawan sunni-mazhabỉ lintas mazhab lintas negara selama ini.

Terlepas dari "krisis" dalam bidang studi-studi keislaman sebagaimana penulis uraikan di atas, khusus berkaitan dengan sistem demokrasi, prinsipprinsip hak asasi manusia, sistem pemilu, sistem ketatanegaraan, dialog lintas-iman, dan konsep-konsep yang selama ini kita adopsi dari barat, tetap kita harus akui sebagai sebagai sebuah kontribusi berharga barat terhadap dunia kita Islam. Sejarah membuktikan, tradisi dan manhaj kaum sunnimazhabī sejak awal adalah manhaj akidah, fiqh, siyasah dan amaliah yang paling siap dan matang dalam mengahadapi berbagai perubahan dunia.

113 Mohammed M Almutari, "Control of Al-Hasa (Saudi Arabia) And Direct Contact With Britain (1910-1916)", Journal of Humanities and Social Science, Issue: 5, Vol. 2, (August 2018), 124-153. Adnan Khan, 100 Years of the Middle East: The Struggle for the Post SykesPicot Middle East, (Egypt: MaktabaIslamia, 2016), h. 55. 


\section{Daftar Pustaka}

'Āmir al-Kurdi, al-'Uqdah al-Salafiyah min al-Muqaddasāt al-Islāmiyyah, Beirūt: Dār al-Kātib al-'Arabī, 1425H/2004M.

'Abd al-Wahhāb, 'Abd al-Raḥmān bin Ḥasan bin Muḥammad bin. Fatḥ al-Majīd li Sharh Kitāb al-Tawhìd, taḥqiq al-Walid bin 'Abd al-Raḥmān bin Muhammad Âlū Fariyyān, Cet. Ke-8, Riyāḍ: Dār al-Muayyad, $1423 \mathrm{H} / 2002 \mathrm{M}$.

'Abd al-Wahhāb, 'Abd al-Rạ̣mān bin Ḥasan bin Muhammad bin. Qurrah 'Uyūn al-Muwaḥhidin, taḥqiq Sa īid bin Naṣr Sayyid Muhammad, Riyạ̣̄: Maktabah al-Rushd, $1421 \mathrm{H}$.

'Ilyān al-Ḥanbali, Muṣtafā Ḥamdūn. Al-Hanābilah wa al-Ikhtilāf ma'a alSalafiyyah al-Mu'āsirah Fì al-'Aqāid wa al-Fiqh wa al-Tasawwuf, Dār alNür al-Mubin, 2014M.

'Uthaimin, Șāliḥ. Al-Shaikh Muhammad bin 'Abd al-Wahhāb Hayātuh Wa Fikruh, Riyạ̄: Dār al-'Ulum, 1416H.

"Piagam Komite Hijaz", dalam Pengurus Besar Nahdlatul Ulama (PBNU), Ensiklopedi Nahdlatul Ulama: Sejarah, Tokoh dan Khazanah Pesantren, Jilid 1, Jakarta Pusat: Mata Bangsa dan PBNU, 2013.

Akoff, Linda Martin. "Philoshophy and Philosophical Practice: Eurocentrism as an Epistemology of Ignorance", dalam James Kids, Jose Medina, Gaile Pohlhaus, (Eds.), The Routledge Handbook of Epistemic Injustice, London \& New York: Routledge Taylor \& Francis Group, 2017.

Al-Ālūisì, Maḥmūd Shukrī. Tãrikh Najd al-Hadith, tahqīiq Muhammad Bahjah al-Atharì, Cet. Ke-3, Baghdād: Dār al-'Alim li al-Nashr, 1415H/1929M.

Al-Azharī al-Shāfi ‘َi al-Ash'arī, Usāmah Sayyid Maḥmūd Muḥammad. Al-Haqq al-Mubìn fí al-Radd 'alā Man Talā'aba bi al-Dìn, Cet. Ke-2, Abū Dhabī: Dār al-Faqih li al-Nashr wa al-Tawzi', 1436H/2015M.

Al-Barrāk, 'Abd al-Raḥmān bin Nāṣir. Sharḥ al-'Aqīdah a-Ṭahāwiyyah, taḥqīi 'Abd al-Raḥmān bin Ṣāliḥ al-Sudais, Cet. Ke-1, Riyāḍ: Dār alTadmiriyyah, $1429 \mathrm{H} / 2008 \mathrm{M}$. 
Al-Barrāk, 'Abd al-Raḥmān bin Nāṣir. Sharḥ al-Uṣūl al-Thalāthah Li al-Imām al-Mujaddid Muhammad bin 'Abd al-Wahhāb, tarji' 'Abd al-Rạ̣mān bin Șālih al-Sudais, Riyāḍ: Muassasah Sabkah Nūr al-Islām, 1424H.

Al-Barrāk, 'Abd al-Raḥmān bin Nāṣir. Sharḥ Nawāqị̣ al-İmān Li al-Imām alMujaddid Muhammad bin 'Abd al-Wahhāb, tarji' 'Abd al-Raḥmān bin Șāliḥ al-Sudais, Riyāọ: Muassasah Sabkah Nūr al-Islām, 1424H.

Al-Būṭì al-Shāfi ‘̄i al-Ash'arì, Ramadhan. Al-Jihād fī al-Islām Kaifa Nafhamuhu wa Kaifa Numārisuhu, Cet. Ke-1, Dimashqi: Dār al-Fikr, 1414H/1993M.

Al-Būṭì al-Shāfi`ì al-Ash'arī, Ramadhan. Al-Lāmazhabiyyah Akhṭar Bid'atin Tuhaddidu al-Shari' ${ }^{\prime} a h$ al-Islāmiyyah, Süriyah: Dār al-Farābī, $1426 \mathrm{H} / 2005 \mathrm{M}$.

Al-Büțì al-Shāfi`ì al-Ash'arì, Ramadhan. Al-Salafiyyah Marḥalah Zamāniyyah Mubārakah La Mazhabun Islāmiyyun, Dimashqi: Dār al-Fikr, 1998M.

Al-Fiqī, Muḥammad Ḥāmid. Azhār min Riyāạ̣: Șirah al-Imām al-'Ādil 'Abd al'Azīs bin 'Abd al-Raḥmān al-Faișal Allu Su' ùd, taḥqiq 'Uthmān al-Mișrī, Cet. Ke-1, Riyad: Maktabah al-Mawrid, 1429H/2008M.

Al-Jabbār al-Maskūmamābānī, Muḥammad Faqīh bin 'Abd. Al-Nuṣuṣ alIslāmiyyah $F \bar{i}$ al-Radd 'alā Madhhab al-Wahhābiyyah, taqrīz wa takhrij Shaikh Maimūn Zubair dan Shaikh 'Abd al-'Azīs Mashhūri, Bogor: Șahịfah Li al-Ṭibā' ah wa al-Nashr, 1436H/2015M.

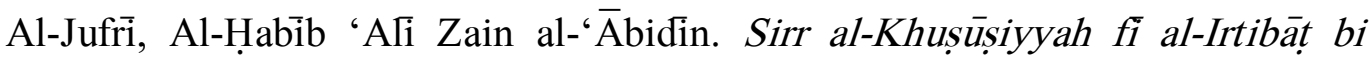
Khair al-Bariyyah, taqrīz 'Umar bin Muhammad bin Sālim bin Hafīz, Cet. Ke-3, Abū Zabì: Dār al-Faqīh, 1435H/2014M.

Al-MadkhaIì, Rabī' bin Hāđì. Al-Firqah al-Nājiyyah Ușūluhā wa 'Aqā'iduhā, Cet. Ke-1, al-Jazäir: al-Mirāth al-Nabawī, 2009M.

Al-Madkhali, Rabi' ' bin Hādì Sadd 'Udwān al-Mulhidìn wa Hukm al-Isti' ānah 'alā Qitālihim bi Ghair al-Muslimīn, Cet. Ke-1, Riyāḍ: al-Furqān, 1411H.

Almutari, Mohammed M. "Control of Al-Hasa (Saudi Arabia) And Direct Contact With Britain (1910-1916)", Journal of Humanities and Social Science, Issue: 5, Vol. 2, August 2018.

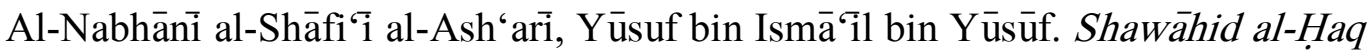
Fī al-Istighāthah Bi Sayyid al-Khalq Salla Allāh 'Alaih Wa Sallam, taṣhịị 
'Abd al-Wārith Muhammad 'Ali, Cet. Ke-3, Beirūt: Dār al-Kutub al'Ilmiyyah, 1428H/2008M.

Al-Qaḥtạnī, 'Abd Allāh. Hāulā’̀ Hum al-Khawārij: Ad'iyā'u al-Salafiyyah alWahhābiyyah, Muassasah Dār Kitāb al-Islāmi: Maṭba'ah Satar, $1425 \mathrm{H} / 2005 \mathrm{M}$.

Al-Saqqāf Al-Ḥusainī al-Shāfíci, Ḥasan 'ATi. Al-Salafiyyah al-Wahhābiyyah: Afkāruha al-Asāsiyyah wa Judhūruha al-Asāsiyyah, Beirūt: Dār al-Mizān, $1430 \mathrm{H} / 2009 \mathrm{M}$.

Al-Ṭā'ì, Najāh. Al-Wahhābiyyūna Khawāriju Ummi Sanah, Cet. Ke-1, Beirūt: Dār al-Mizān, 1426H/2006.

Al-Ṭayyib, Aḥmad Muḥammad. Man Hum Ahl al-Sunnah wa al-Jamā'ah, dalam Mu'tamar al-Shīshān: Bayān wa Tawșif Manhaj Ahl al-Sunnah wa alJamā'ah I'tiqādan wa Fiqhan wa Sulūkan, Grozny-Chechnya, 25 Agustus 2016.

Al-Wadī'i, Muqbil bin Hādì. Hādihi Da' watunā Wa 'Aqìdatunā, Cet. Ke-2, Yaman: Dār al-Āthar, 1429H/2008M.

Al-Wahhāb, Muhammad bin 'Abd. Mufīd al-Mustafíd Fī Kufri Tārik alTawhīid, Cet. Ke-1, al-Dawlah al-Islāmiyyah Khilāfah 'alā Manhaj alNubuwwah: Maktabah al-Himmah, 1436H.

Al-Wahhāb, Muhammad bin 'Abd. Mufīd al-Mustafìd Fī Kufri Tārik alTawhìd, Cet. Ke-1, (al-Dawlah al-Islāmiyyah Khilāfah 'alā Manhaj alNubuwwah: Maktabah al-Himmah, 1436H).

Al-Wahhāb, Muhammad bin 'Abd. Kashf al-Shubhāt, Cet. Ke-1, Dār 'Umar bin al-Khaț̣āb, 1430H/2009M.

Al-Wahhāb, Muhammad bin 'Abd. Kashf al-Shubhāt, Cet. Ke-1, Dār 'Umar bin al-Khațāab, 1430H/2009M.

Al-Wahhāb, Muhammad bin 'Abd. Kitāb al-Tawhịd alladhìi Huwa Haqq Allāh 'alà al-'Abìid, Beirūt: Manshūrāt Dār Maktabah al-Ḥayāt, $1390 \mathrm{H} / 1970 \mathrm{M}$.

Al-Wahhāb, Muhammad bin 'Abd. Kitāb al-Tawhịd alladhì Huwa Haqq Allāh 'alà al-'Abìd, Beirūt: Manshūrāt Dār Maktabah al-Ḥayāt, $1390 \mathrm{H} / 1970 \mathrm{M}$. 
Al-Wahhāb, Muhammad bin 'Abd. Masāil al-Jāhiliyyah allatī Khālafa Fīhā Rasūi Allāh Salla Allāh 'Alaihi wa Sallama Ahla al-Jāhiliyyah, tahqīi Muhammad Shukrī al-Ālūsi, al-Qahirah: al-Matba'ah al-Salafiyyah wa Maktabataha, $1436 \mathrm{H}$.

Al-Wahhāb, Muhammad bin 'Abd. Masāil al-Jāhiliyyah allatī Khālafa Fīhà Rasūl Allāh Salla Allāh 'Alaihi wa Sallama Ahla al-Jāhiliyyah, taḥqiq Muḥammad Shukrì al-Ālūsi, al-Qahirah: al-Matba'ah al-Salafiyyah wa Maktabataha, $1436 \mathrm{H}$.

Al-Wahhāb, Sulaimān bin 'Abd. al-Sawā'iq al-Ilāhiyyah Fì al-Radd 'alā alWahhābiyyah, Cet. Ke-3, Istanbūl-Turki: Ikhlās Wavki Yayindir, 1399H/1979M.

Bāz, 'Abd al-'Azīz bin. Al-Imām Muhammad bin 'Abd al-Wahhāb Da'watuh wa Siratuh, Cet. Ke-2, Riyāḍ: al-Riāsah al-'Āmmah, 1411H.

Bidwell, Robin Leonard. Travellers in Arabia, New York: The Hamlyn Publishing Group Limited, 1976.

Bishr, 'Uthmān bin 'Abd Allāh Ibnu. 'Unwān al-Majdi Fī Tārīkhi Najd, tạ̣qīq 'Abd al-Rahmān bin 'Abd al-Lațîf Ālū al-Shaykh, Cet. Ke-4, Riyāḍ: Därah al-Malik 'Abd al-'Azìz, 1402H/1982M.

Blanc, Vincent Le. The World Surveyed, translated from French into English by F.B. Gent, London: John Starkey at the Miter, 1660M.

Bonacina, Giovanni. The Wahhabis Seen through European Eyes (1772-1830): Deists and Putitan of Islam, Leiden and Boston: Brill, Volume 1, 2015.

Brydges, Sir Harford Jones. An Account of the Transactions of the Majesty's Mission to the Courth of Persia in the Years 1807-1811 with Notes on the Wahhabiya, London: James Bohn, King William Street, West Strand, Volume I, 1834M.

Burckhardt, John Lewis. Notes on the Bedouins and Wahabys, London: Henry Colburn and Ricard Bentley, 1831M.

Daḥlān, Sayyid Ạ̣mad Zainì. al-Durar al-Saniyyah Fì al-Radd 'alā alWahhābiyyah, ta'nī' Jibrīl Haddād, Cet. Ke-1, Dimashqi: Maktabah alAḥ̣āb wa Dār Ghār Hirā', 1424H/2003M. 
Daḥlān, Sayyid Aḥmad Zainì. Khulāṣah al-Kalām Fī Bayāni Umarā' al-Bilād al-

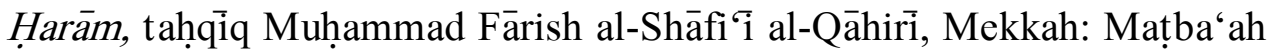
Arḍ al-Ḥaramain, 1035H.

Delong-Bas, Natana J. Wahhabi Islam: From Revival and Reform to Global Jihad, London: Oxford University Press, 2004.

Doughty, Charles Montagu. Travels in Arabia Deserta, London and Boston: Philip Lee Warner, Publisher to the Medici Society, LTD., an Jonatahan Cape, Vol I \& II, 1921M.

Freeth, Zahra., Winstone, HVF. Explorers of Arabia, London: George Allen and Unwin, 1978.

Ghannām, Ḥusain bin Abū Bakar Ibnu. Rawḍah al-Afkār wa al-Afhām li Murtād

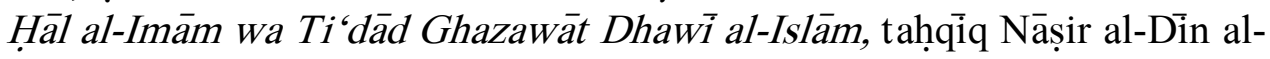
Asad, Cet. Ke-4, Beirut: Dār al-Shurūq, 1415H/1994M.

Ḥusain, Ṭahā. Al-Hayāt al-Adabiyyah Fī Jazìrah al-'Arab, Cet. Ke-1, Damshiq: Maktab al-Nashr al-'Arabi, 1354H/1925M.

Hāshim Ash'arī, Haḍrah al-Shaikh Muhammad. Risālah Ahl al-Sunnah wa alJamā'ah Fi Hadith al-Mawtā wa Ashrāt al-Sā'ah wa Bayāni Mafhūm alSunnah wa al-Bid'ah, taḥqīq Muḥammad 'Iṣām Ḥādiq, Cet. Ke-1, Tebuireng: Aswaja al-I'lāmi, $1418 \mathrm{H}$.

Harās, Muḥammad Khalìl. Al-Harakah al-Wahhābiyyah: Raddun 'alā Maqāl li al-Duktūr Muhammad al-Bahī Fï Naqd al-Wahhābiyyah, Beirut: Dar alKatib al-'Arabi, $1410 \mathrm{H}$.

Hashmi, Sohail H. "'Abd al-Wahhab, Muhammad Ibn (1703-1792)”, dalam Richard C Martin (Eds.), Encyclopedia of Islam and the Muslim World, New York: Thomson Gale, Volume 1, 2004.

Hogarth, David George. The Penetration of Arabia: A Record of the Development of Western Knowledge Concerning the Arabian Peninsula, New York: Frederick A. Stokes Company, 1904.

Hosein, Imran N. The Caliphate, The Hejaz and The Saudi Wahhabi Nation State, New York: Masjid Dar al-Quran, 1996.

Hosein, Imran N. The Caliphate, The Hejaz and The Saudi Wahhabi Nation State, New York: Masjid Dar al-Quran, 1996. 
Hoskins, Halford Lancaster. "Background of the British Position in Arabia", Middle East Journal, Volume 1, 1947.

Hurgronje, Christian Snouck. Mohammadenism: Lectures on Its Origin, Its Religious and Political Growth, and Its Present State, New York: G.P. Putnam's Son, 1916M.

Hurgronje, Christian Snouck. The Revolt in Arabia, with a Foreword by Richard J.H. Gotheil, New York and London: The Knickerbocker Press, 1917M.

Ibnu Ḥumaid al-Najdi al-Ḥanbali, Muḥammad bin 'Abd Allāh. Al-Suhub alWābilah 'alā Darā'iḥa al-Hanābilah, Makkah: Maṭba'ah al-Imām Aḥmad, 1416H/1996M.

Jān al-Ḥanafî, Khawājah Muḥammad Ḥasan. Al-Ușūl al-Arba'ah Fī Tardìd alWahhābiyah, taḥqiq Hakīm Muḥammad Mi'rāj al-Dīn Aḥmad, IstānbūlTurkì: Darussefaka, Isik Kitabevi, 1431H/2010M.

Jum'ah al-Shāfi ‘i al-Ash'arì, 'ATi. al-Bayān al-Qawìm li Taṣhịh Ba'd alMafāhìm, al-Qāhirah: Dār al-Sundus, 1428H/2007M.

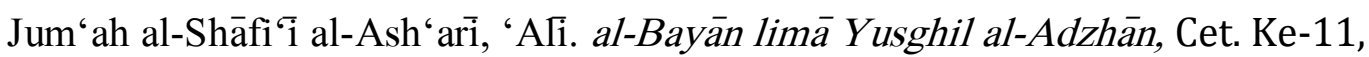
al-Juz al-Ūlā, al-Qāhirah: Dār al-Maqtam li al-Nashr wa al-Tawzì', $1426 \mathrm{H} / 2005 \mathrm{M}$.

Jum'ah al-Shāfi'i al-Ash'arì, 'A Ali. Al-Mutashaddidūn Manhajuhum wa Munāqashat Ahhami Qadāyāhum, Cet. Ke-1, al-Qāhirah: Dār al-Maqțam li al-Nashr wa al-Tawzi', 1432H/2011M.

Khan, Adnan. 100 Years of the Middle East: The Struggle for the Post SykesPicot Middle East, Egypt: MaktabaIslamia, 2016.

Laoust, Henri. "Ibn 'Abd al-Wahhab", dalam B. Lewis, VL. Menage, CH. Pellat, Joseph Schacht (eds). The Encyclopaedia of Islam: New Edition, Volume III, H-IRAM, Leiden: E.J Brill and London: Luzac \& Co., 1986.

Lawrence, TE. Seven Pillars of Wisdom: A Triumph, Cet. Ke-1, Delhi: Oxford University Press and Bombay Calcutta Madras, 1940.

Leblich, Domingo Badia Y. Travels of Ali Bey, London: Longman, Hurst, Fees, Orme, and Brown, 1816M. 
Lewis, Bernard. The Arab in History, London: Hutshinson House \& Anchor Press, Ltd., Second Edition, 1954.

Low, Michael Cristhoper. "Empire of Hajj: Pilgrims, Plagus, and Pan-Islam under British Surveillance 1865-1926", Thesis, George State University, (July, 2007), 5-6.

Mansbach, Richard. "Calvinism as a Precedent for Islamic Radicalism", The Brown Journal of World Affairs, Vol. 12, No. 2, Winter/Spring 2006.

Margoliouth, David Samuel. "Wahhabiya", dalam HAR Gibb dan JK Kramers (Eds), Shorter Encyclopaedia of Islam, Leiden: EJ Brill, 1953.

Mu'tamar al-Shīshān, Naș Bayān Mu'tamar Man Hum Ahl al-Sunnah wa alJamā'ah Bayān wa Tawșî́ Manhaj Ahl al-Sunnah wa al-Jamā'ah I'tiqādan wa Fiqhan wa Sulūkan, Grozny-Chechnya, 25-27 Agustus 2016.

Mughniyyah, Muḥammad Jawwād. Hāâhì Hiya al-Wahhābiyyah, Qaṭar: Muassasah Dār Kitāb al-Islāmī: Mațba'ah Satar, 1427H/2007M.

Nasira, Hani. "Salafist Challenge al-Azhar for Ideological Supremcy in Egypt", Terrorism Monitor, Vol III, Issue 35, September 212, 2010.

Ochsenwald, William. Religion, Society and the State in Arabia: The Hijaz under Ottoman Control 1840-1908, Columbus: Ohio State University Press, 1984.

Palgrave, William Gifford. A Personnal Narrative of A Year's Journey Through Central and Eastern Arabia 1862-1863, London and New York: Macmillan and Company, Sixth Edition, 1873M.

Philby, Harry St. John. Arabia of the Wahhabis, New York: Arno Press, 1973.

Ralli, Augustus. Christians at Mecca, London: William Heinemann, 1909.

Rentz, George Snavlye. "Muhammad Ibn 'Abd al-Wahhab and the Beginnings of the Unitarian Empire in Arabia", Dissertation of University of California at Barkeley, 1948.

Rị̣ā, Muḥammad Rashīd. Al-Wahhābiyyūn wa al-Hijāz, Cet. Ke-1, Miṣrāă Maṭba'ah al-Manār, 1344H.

Sạ̣mān, Sulaimān bin. Al-Hadiyyah al-Saniyyah wa al-Tuḥfah al-Wahhābiyyah al-Najdiyyah, Cet. Ke-1, Mișrā: Maṭba'ah al-Manār, 1342H. 
Said, Edward W. Orientalism, London: Penguin Books, 1978.

Salibi, Kamal Suleiman. A History of Arabia, New York: Caravan Books, 1980.

Shākir, Maḥmūd Muhammad. Hukm al-Jāhiliyyah, Riyāḍ: Maktabah al-Sunnah, 1991.

Shariff, Sayyid Sharif ibnu 'Abd Allāh Sayyid. Sidqu al-Khabar Fï Khawāriji alQarni al-Thānī 'Ashar, Mișrā: Maṭba'ah Kaumain al-Laẓfiyyah, $1428 \mathrm{H} / 2008 \mathrm{M}$.

Smalley, William F. "The Wahhabis and Ibn Saud”, Muslim World, 22, 1932M.

Sulaimān bin 'Abd Allāh bin Muhammad bin 'Abd al-Wahhāb, Al-Dalāil fi Hukm Muwālāh Ahl al-Ishrāk wa Awthaq 'Urā al-Īmān, Cet. Ke-1, Irāq: Maktabah al-Himmah-al-Dawlah al-Islāmiyyah 'ala Minhaj alNubuwwah, 1436H.

Sulaimān bin 'Abd al-Wahhāb, Faṣl al-Khițāb min Kitābi Allāh wa al-Hadithi al-Rasūl wa Kalāmi al-Ulamā' Fì Madhhabi Muhammad bin 'Abd alWahhāb, Cet. Ke-3, Istanbūl-Turki: Maktabah 'Ishiq Kitabevi, 1399H.

Tidrick, Kathryn. Heart-Beguiling Araby, New York: Cambridge University Press, 1981.

Trautz, M. "G.A. Wallin and the Pnenetration of Arabia", The Geographical Journal, 76, August 1930.

Varthema, Ludovico di. The Travels of Ludovico Di Varthema in Egypt, Syria, Arabia Deserta and Arabia Felix in Persia, India and Ethiopia 15031508, translated from Italian by John Winter Jones, London: Printed for Hakluyt Society, 1863.

Wallen, John. "Burton in Makkah and Medina: Sufi Aspirant or Imperialist Spy?", Journal of University of Nizwa, Issue: 2.3, 2014.

William, Patick., Chrisman, Laura (Eds.), Colonial Discourse and Post-Colonial Theory: A Reader, London and New York: Routledge Taylor \& Francis Group, 2013.

Winder, Ricard Bayly. Saudi Arabia in the Nineteenth Century, New York: St. Martin's Press, 1965.

Zwemer, Samuel. "Islam in Arabia Deserta”, Muslim World, 33, 1943. 